\title{
Illustrating the Ostracized : the Depiction of Villain, Soldier and Jew in the Passional of Abbess Cunegund*
}

\section{JENNIFER VLČEK SCHURR}

Schurr Vlček, Jennifer: Illustrating the Ostracized: the Depiction of Villain, Soldier and Jew in the Passional of Abbess Cunegund

The first treatise of the so-called Passional of Abbess Cunegund was composed by the Dominican lector Colda of Colditz at the abbess' behest in 1312, and illustrated by an unknown artist. In this study, images of three specific character-types are analysed: villain, soldier and Jew, who not only act out their part in the treatises' account of Christ's Passion, but also appear to provide a window onto certain aspects of contemporary, medieval Czech society. By examining the iconography of the illustrations it is shown how, through characterisation, caricature and dress, the viewer is led to adopt an attitude either of disgust towards the malefactors, or a certain sympathy towards a chosen few.

Key Words Passional of Abbess Cunegund; Medieval Czech Art; Medieval Manuscript; Jews; Iconography

doi.org/10.15452/Historica.2021.12.0006

Contact freelance researcher; jsvschurr@gmail.com

The manuscript known as the Passional of Abbess Cunegund (1312-1314) opens with a spiritual exercise constructed around the Instruments of the Passion, or Arma Chris$t i .^{1}$ The Instruments are represented, in both the text and illustrations, as the 'weapons' with which Christ overcame the power of Satan. This treatise - the first of five that make up Cunegund's florilegium - was composed in 1312 by the Dominican lector, Colda of Colditz, at the behest of the daughter of King Otakar II of Bohemia: Cunegund, Abbess of the Benedictine Convent of St. George in Prague (b. end of January 1265-d. 27 November 1321). ${ }^{2}$ Colda enjoins the reader to exploit the apotropaic properties of the Passion Instruments. Each object, and its place in the narrative of Christ's suffering and death, is considered in the text, which is accompanied by a comprehensive series of images. The images, particularly the fine Andachtsbild on fol. 10r, provide a focus for pious and meditative contemplation. The reader is entreated: Non recedant de ore; non avellantur

\footnotetext{
I am most grateful for the encouraging and helpful input of the anonymous reviewers and thank them for their constructive comments.

1 Národní knihovna České republiky (hereinafter NKČR), MS XIV A 17. The collection of medieval manuscripts from the Convent of St. George are held in the National Library of the Czech Republic. This manuscript is now known as the Passional of Abbess Cunegund, see URBÁNKOVÁ, Emma: Historický úvod [Historical introduction]. In: URBÁNKOVÁ, Emma - STEJSKAL, Karel: Pasionál Přemyslovny Kunhuty : Passionale Abbatissae Cunegundis [The Passional of Abbess Cunegund]. Praha 1975, pp. 11-20, at p. 12. It is, however, best described as 'an illustrated florilegium' as suggested by HAMBURGER, Jeffrey: The Rothschild Canticles : Art and Mysticism in Flanders and the Rhineland c.1300. New Haven 1990, p. 159.

2 First treatise, 1312, composed by Colda of Colditz, written up by Beneš, canon of the Basilica of St George, illustrated by the Master of the Passional. NKČR, MS XIV A 17, fols. 1v-10r.
} 
a corde tuo; non au/ferantur ab oculis tuis suae passionis insignia. ${ }^{3}$ The master artist made use of established Passion iconography that is, however, distinguished by some specifically individualized details. This is demonstrated in his representations of the villain, soldier and Jew - three categories of 'other' that feature prominently in the illustrations of the first Passional treatise. In these illustrations of these typecast figures, Cunegund and the nuns of St. George's Convent were afforded a view of 'outsiders,' familiar in contemporary society but from whom the Benedictine sisters were sheltered by the confines of enclosure. Villain, soldier and Jew play a vital role in the composition of the pictures that they inhabit and were, within the context of the first Passional treatise, also designed to be meditated upon by the reader, reminding them of the anguish and torment that was inflicted by these characters. They represent a manifestation of sin, violence and evil.

Each category - that of villain, soldier and Jew - represents a societal group judged to be antagonistic towards Christ and/or Christians. They are all depicted wearing medieval dress, lending them an air of contemporaneity, whilst also easily distinguishing them from the main, positive, protagonists of the treatise - Christ and his entourage - who wear so-called 'biblical dress'. ${ }^{4}$ Villain, soldier and Jew are not only characterized by the artist but also caricatured. In this, the artist followed a widespread western, medieval, iconographic convention which fed into locally established, and often strongly held, negative attitudes directed by the society of the day towards those dwelling on its fringes. They might at the very least provoke suspicion in their contemporary world, but in the Passional they are presented as their aggressive and violent allegorical and biblical counterparts. Each, and by extension all those belonging to their 'kind', is deemed responsible for perpetrating specifically anti-Christian acts. These individuals - villain, soldier and Jew - are exhibited by the artist to Cunegund and her nuns, not only as the perpetrators of these acts but as vehicles of evil and objects of loathing.

\section{Villain}

The first negative 'other' encountered in the manuscript is a villain who is illustrated three times in a series of small action-narratives on fol. $3 \mathrm{v}$ (Figure 1): in the second, third and fourth of six vignettes. He is depicted seducing a young maiden (an allegorical representation of Man's rational soul, betrothed to the noble sponsus Christ) and abducting her before meeting his most gruesome end. The villain is unattractively type-cast: portrayed as ugly, bare-legged, and in a short, plain tunic. ${ }^{5}$ In all of the fol. $3 \mathrm{v}$ images, he is portrayed in strict profile: an iconographic short-hand for the sinful malefactor. ${ }^{6}$ (It will be noted that several other representations of Jews in the first treatise of the Passional are similarly depicted in profile.) His hair is thick, spiky and coarse, following a western artistic con-

\footnotetext{
3 Do not let the Instruments of his Passion away from your face; do not let them be torn from your heart; do not let them be taken from your eyes. NKČR, MS XIV A 17, fol. 9v, lines 2-3.

$4 \quad$ Standard 'biblical dress' depicts male figures, usually barefoot, wearing a rectangular cloak or pallium wrapped around the body and diagonally over the left shoulder, over a plain tunic: clothing derived from ancient Greek and Roman attire. SCOTT, Margaret: Medieval Dress and Fashion. London 2009, p. 13.

5 The principle of outer body reflecting inner being was established by the Greeks and adapted in the Middle Ages, STRICKLAND, Debra Higgs: Saracens, Demons and Jews : Making Monsters in Medieval Art. Princeton Oxford 2003, pp. 37-38.
}

$6 \quad$ ROSEWELL, Roger: Medieval Wall Paintings in English and Welsh Churches. Woodbridge 2008, p. 124. 


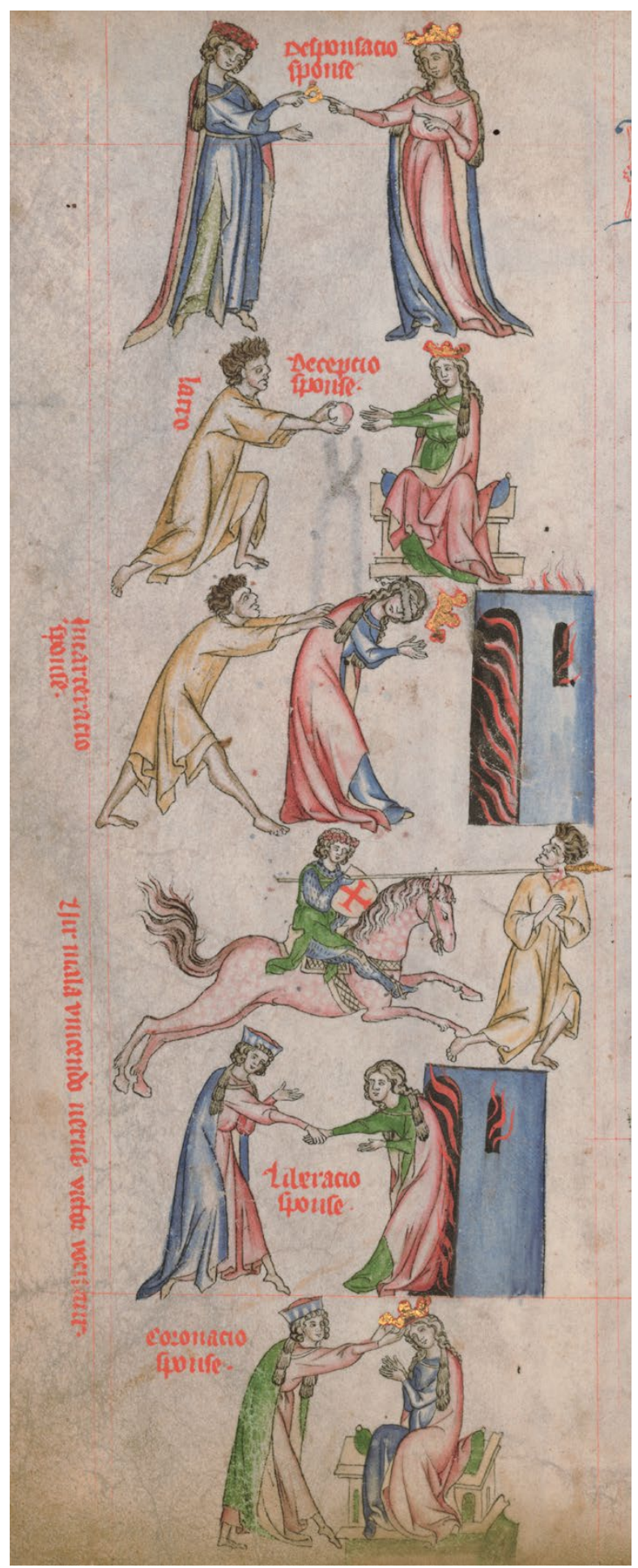

Figure 1. Parable Scenes, Passional of Abbess Cunegund, MS XIV A 17, fol. 3v, 1312, Národní knihovna České republiky, Praha. 
vention which signals him to be a wicked barbarian (Figure 2). ${ }^{7}$ Many miles away, in the Church of St. George, Kelmscott, Oxfordshire, the miscreant Cain is similarly depicted in a contemporary late-thirteenth-century medieval wall painting, wearing a plain tunic and with untamed hair (Figure 3). This serves to demonstrate the international reach of the 'language' of iconographic detail. I believe that the unkempt appearance of both Cain and the Passional villain illustrates Debra Higgs Strickland's observation that, 'monstrosity was a metaphor for unacceptability, both cultural and religious'. ${ }^{8}$ Later examples in Bohemian manuscripts illustrate the perpetuation of this iconography, for example the striking profile image of the executioner tying off St. Peter's feet at his crucifixion, fol. $177 \mathrm{v}$ of the Velislav Bible, c. $1340 ;^{9}$ the wild hair of the Prodigal son illustrated in mid-fourteenth-century Liber Depictus ${ }^{10}$ and the figures of the Poor in the scene of St. Hedwig's pledge of Chastity, fol. 18r of the Vita Beatae Hedwigis, 1353, where the artist incorporates unflattering grimaces, tousled hair and profile depiction in his illustration of these social outcasts. ${ }^{11}$ The uncultured seducer on fol. $3 \mathrm{v}$ of the Passional, rudely thrusts forward to beguile the sponsa/lady-love, in direct contrast with the idealized chivalrous noble lover in the image directly above who leans away demurely and coyly with utmost courtly civility, chastely offering a ring: a gesture full of religious, chivalrous and secular meaning (Figure 1). ${ }^{12}$ It should be noted that this figure is equally caricatured: his noble status signalled by his stately robes and neat coiffure - in the last two scenes he sports a distinctive dorlott. This curled fringe was the height of contemporary, male, courtly fashion. ${ }^{13}$ The Passional villain kneels to proffer a love-token, adopting, as Gia Toussaint notes, the minne pose of a lover offering his heart. ${ }^{14}$ Here, the artist creates a parody of chivalric etiquette by replacing the customary heart with an apple. ${ }^{15}$ The apple in turn

\footnotetext{
7 STRICKLAND, D. H.: Saracens, p. 38; ROSEWELL, R. : Medieval Wall Paintings, p. 124.

8 STRICKLAND, D. H.: Saracens, p. 8.

$9 \quad$ NK ČR, MS XIII C 124.

10 Österreichische Nationalbibliothek, Wien, MS 370, Liber Depictus, illustrated in: STEJSKAL, Karel: Pasionál Přemyslovny Kunhuty [The Passional of Abbess Cunegund]. In: URBÁNKOVÁ, E. - STEJSKAL, K.: Pasionál, pp. 21-146, at p. 122.
}

11 J. Paul Getty Museum, MS Ludwig X17 (83 MN 126). I am grateful to the anonymous reviewer for drawing attention to the fact that within the latter manuscript a broad range of personae are categorised as 'other' by the use of a distinctive, unattractive profile: devil, sinners, Jews, heretics, possessed people, sick people, personifications of Death or Sin, murderers and executioners, dying figures, pagans and animals (the last mentioned connecting all these figures with bestiality, carnality and the lack of a soul).

12 The betrothal ring, together with a crown, was also an important element in a nun's dedication service, MUSCHIOL, Gisela: Time and Space : Liturgy and Rite in Female Monasteries of the Middle Ages. In: HAMBURGER, Jeffrey F. - MARTI, Susan (eds.): Crown and Veil : Female Monasticism from the Fifth Century to the Fifteenth Centuries. New York 2008, pp. 191-206, at pp. 196-197. William Durand described the significance of the bishop's ring as 'a pledge of the faith with which Christ has married his spouse, the Holy Church', adding that its circularity and that it is gold represents the perfection of the gifts of the Holy Spirit in Christ, DURAND OF MENDE, William: Rationale divinorum officiorum, Books 2-3. In: THIBODEAU, Timothy M. (transl.): William Durand: On the Clergy and Their Vestments. Chicago 2010, p. 195. The betrothal ring on NKČR, MS XIV A 17, fol. $3 \mathrm{v}$ is one of the few gilded objects in the Passional.

13 VAN BUREN, Anne - WIECK, Roger S.: Illuminating Fashion : Dress in the Art of Medieval France and the Netherlands, 1325-1515. New York 2011, p. 40; French dorloter - to pamper.

14 TOUSSAINT, Gia: Das Passional der Kunigunde von Böhmen : Bildrhetorik und Spiritualität [The Passional of Abbess Cunegund: The Artistic Eloquence and Spirituality]. Paderborn 2003, p. 92.

15 Ibid. pp. 89 and 92, believes this to be a mirror, representing vanitas. Comparison with the fruit depicted on the Tree of Knowledge on NKČR, MS XIV A 17, fol. 4v makes it clear that it is an apple that the villain offers. 
Figure 2. Detail. Villain, Parable Scenes, Passional of Abbess Cunegund, MS XIV A 17, fol. 3v, 1312, Národní knihovna České republiky, Praha.

Figure 3. Detail. Cain, Story of Cain and Abel, $13^{\text {th }}$ century wall painting, St. George's Church, Kelmscott, Oxfordshire. [With kind permission of the incumbent of the Shill Valley and Broadshire Benefice.]
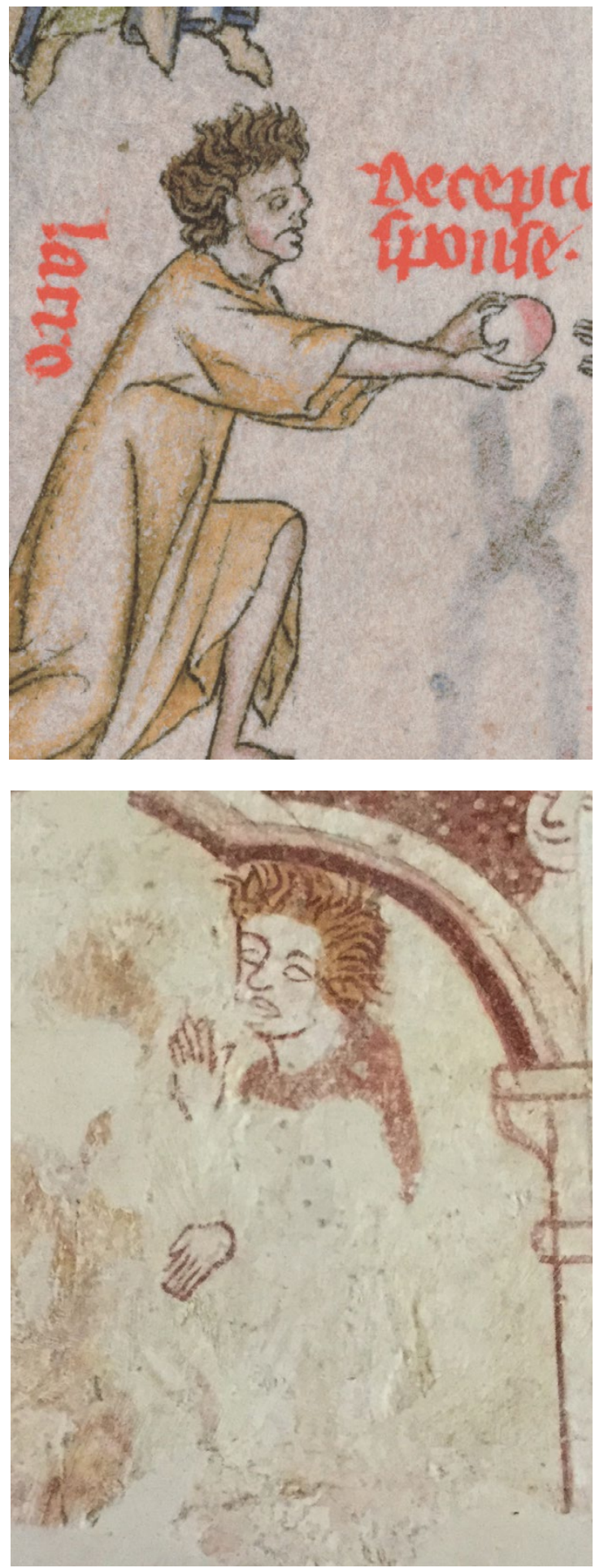
recalls the Fall of Man as a result of Eve's temptation in the Garden of Eden. ${ }^{16}$ The artist illustrates one of society's basest members mimicking one of its most refined: a world-turned-upside-down, typical in medieval imagery. ${ }^{17}$

In the following scene-the third in the fol. 3v series (Figure 1) - the same villain pushes the lady-love into a flaming tower, employing an obvious reversal of the iconography of Christ rescuing humanity in the Harrowing of Hell on fol. 9r (Figure 4): a comparison no doubt intended to send a shiver of recognition through the observer. Finally, in the fourth vignette, the brigand is depicted being run through the neck by the lance of the beautiful lover-knight. Once again, the base villain starkly contrasts the noble figure of the knight. The heroically triumphant Christ-figure is fine-featured, with his hair neatly curled, and immaculately turned out. Perhaps, however, the villain's clasped hands and eyes turned heavenwards indicate some ultimate remorse and a plea for forgiveness. Whilst illustrating a secular allegory of Christ the Lover-knight rescuing the human soul, the vignettes also provide a thinly veiled summary of the events of Cunegund's life, typifying the medieval appreciation of layered meaning..$^{18}$ Contemporary dress supports this particular interpretation as well as lending the parable the air of a courtly romance. For Cunegund, the image of a virgin lured away by a seductive figure of evil may have held an overwhelming personal (and religious) significance; for other readers of the Passional, this man in the guise of a social out-cast represents the embodiment of evil.

\section{Soldier}

Just as the artist uses facial expression as a means of displaying the evil nature of the villain on fol. $3 \mathrm{v}$, so the appearance of grim determination on the face of the Roman soldier in the top image on fol. $6 \mathrm{v}$ mirrors the violent malevolence of his intent (Figure 5). As with the fol. $3 \mathrm{v}$ villain, the soldier's expression is down-mouthed but, rather than depicting him in profile, the artist has turned his head, offering a three-quarter view that reveals his set jaw with the corners of his mouth pulled wide in an ugly leer. This once again reflects an iconographic trend witnessed elsewhere in western art, for example in the person of a slaughtering soldier in the De Lisle Psalter's image of the Murder of the Innocents. ${ }^{19}$ The Passional fol. 6v soldier is depicted unsympathetically as a contemporary man-at-arms. I suggest that this figure would have evoked the memory of the mercenaries who had been called in by the King of Bohemia, Henry of Carinthia, in 1310, in his attempt

\footnotetext{
16 The significance of the representations on NKČR, MS XIV A 17, fols. 3v and 4v, is discussed in a forthcoming publication, VLČEK SCHURR, Jennifer: Kunigunde: 'Bartered Bride' and Bride of Christ. In: ANTONÍN MALANÍKOVÁ, Michaela - RYWIKOVÁ, Daniela (eds.): Premodern History and Art through the Prism of Gender. Washington D.C.

17 The medieval fascination for ludicrous role-reversal is demonstrated, for example, in the contemporary bas-de-page images in the Metz Pontifical of Reynaud de Bar (1302-1316), Part 1, Fitzwilliam Museum, Cambridge, MS 298, and Part 2, NKČR, MS XXIII C 120; see also CAMILLE, Michael: Image on the Edge: The Margins of Medieval Art. London 1992.

18 STEJSKAL, K.: Pasionál, pp. 35-36. At the age of twenty-six, Cunegund was removed from enclosure as a Poor Clare, where she had been since the age of twelve, and was given in marriage to Boleslav II, Duke of Mazovia, in order to progress her brother's bid for the Polish throne. The significance of the NKČR, MS XIV A 17, fol. $3 \mathrm{v}$ images in depicting Cunegund's life is considered in depth in the forthcoming publication, VLČEK SCHURR, J.: Kunigunde.

19 British Library, Arundel, MS 83 II, fol. 124v.
} 
to the prevent the accession of Cunegund's niece Eliška and John of Luxembourg. ${ }^{20}$ This took place just two years before the production of this treatise. Bloody skirmishes, lasting several days, had broken out on the streets of Prague, culminating in a ferocious battle in front of the gates of the citadel, Hradčany. ${ }^{21}$ This final confrontation cost many lives and took place a mere couple of hundred yards from the Convent of St. George. The fol. 6v soldier - who is helmeted, like the soldiers guarding Christ's tomb illustrated in the scene of the Resurrection on fol. 9r discussed below, indicating a low-ranking foot soldier - is the antithesis of the other military figures found in the Passional: St. George, featured within a shield on fol. 1v (Figure 6), and Christ the Lover-knight pictured in the fourth of the fol. $3 \mathrm{v}$ vignettes (Figure 1), both of whom appear bare-headed and mounted, valiantly fighting for God and Good. Despite this contrast, it is interesting to note that, apart from the helmets or lack of the same, these soldiers, and the fol. 6v Roman guard, all wear the same military dress. The artist identifies 'good' soldiers as crusading knights, and 'bad' soldiers as foot soldiers, playing out their unequivocally negative role in the Passion story. A similar discrimination between the 'worthy' and 'ruthless' is also recognisable in the illustration of Jews, and will be considered below.

The rubric title above the upper fol. 6v illustration merely reads, Hic capitur Christe rex trahiturecce ligatus (Figure 5). ${ }^{22}$ The soldier represents the commander of the troops who, together with the Jewish police, arrested and secured Christ, as described in John's gospel. ${ }^{23}$ The fol. $6 \mathrm{v}$ image flatters neither of these officials. The Roman soldier is presented as wholly negative; his aggression gratuitous. The energetic ferocity of his demeanour directly contrasts the patient passivity of the bound Christ. The Master of the Passional portrays a viciously threatening figure - an enemy - attacking a victim who clearly offers no physical threat. It is, therefore, ironic that the soldier is shown wearing protective mail garments. The medieval viewer would recognise that the mittens, pulled over his hands, demonstrate a readiness for action, and that the blow lined up by the soldier's iron-clad, right fist would be devastating. With his other hand, the soldier grasps Christ's hair. This is a particularly interesting iconographic detail for, despite not being mentioned in the gospels, a fistful of hair commonly features in representations of Arma Christi ${ }^{24}$ It refers to Isaiah's typologically prophetic words: I gave [...] my cheeks to them that plucked off the hair: I hid not my face from shame and spitting. ${ }^{25}$ Significantly, the Jewish official who is depicted together with the Roman soldier in the act of arresting Christ in the fol. $6 \mathrm{v}$ image, is shown to be spitting and thus completing the reference to this biblical verse. Indeed, the image of a spitting Jew also frequently figures among the Passion Instruments depicted in Arma Christi. ${ }^{26}$ The spitting Jew and the fistful of hair are both absent, from the Passional's illustrations of the Arma Christi on fol. 3r and the Man of Sorrows

\footnotetext{
20 For a comprehensive introduction to this period of Bohemian history, in English, see, BENEŠOVSKÁ, Klára (ed.): A Royal Marriage: Elisabeth Premyslid and John of Luxembourg 1310. Exhibition catalogue, English edition. Prague 2011.

21 FIALA, Zdeněk (ed.) - HEŘMANSKÝ, František (transl.): Kronika Zbraslavská : Chronicon Aulae Regiae. Prague 1952, p. 479.

22 Here, Christ the king is captured; behold he is dragged, bound, rubric title, NKČR, MS XIV A 17, fol. 6v.

23 John 18:12.

24 SCHILLER, Gertrude: Iconography of Christian Art, I/2. London: 1971-1972, p. 191.

25 Isaiah 50:6. The Holy Bible, King James’ version. London 1957, p. 687.

26 SCHILLER, G.: Iconography II/2, p. 73.
} 


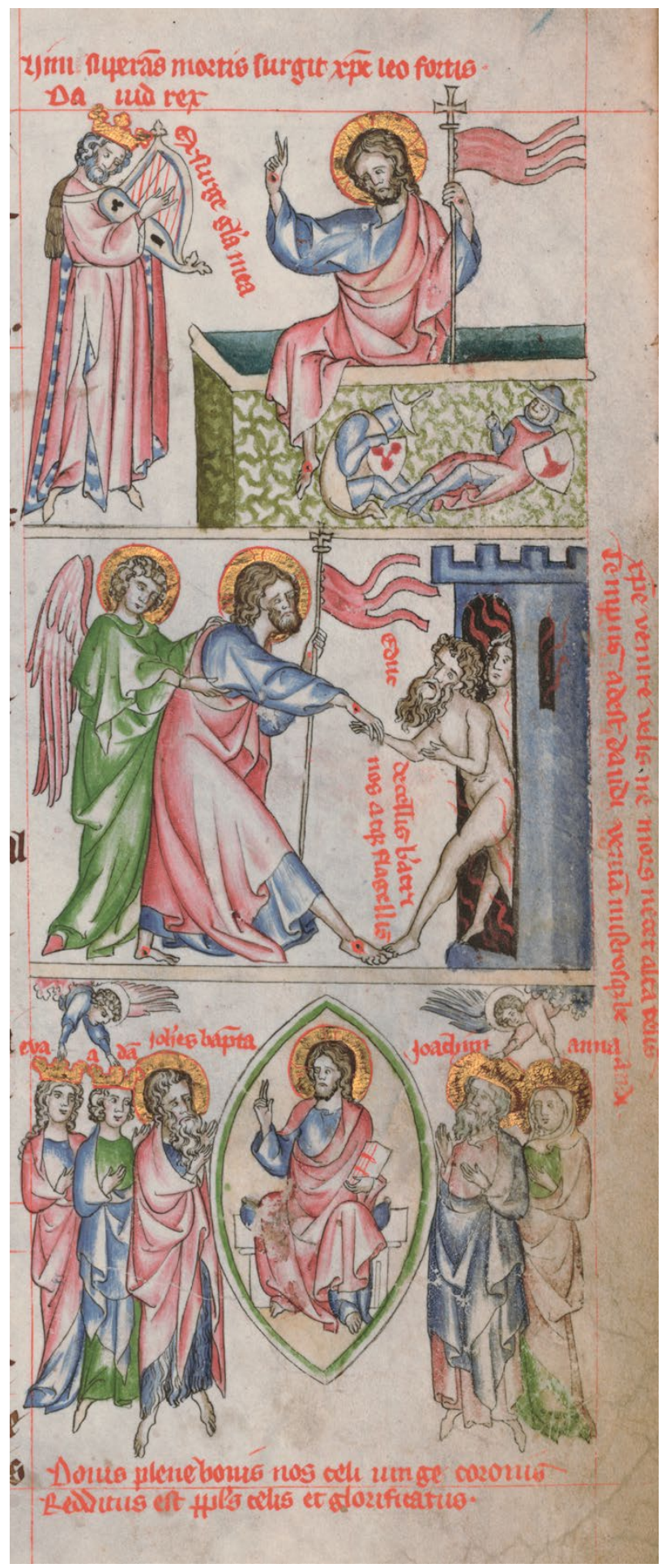

Figure 4. Resurrection/Harrowing of Hell/Last Judgement, Passional of Abbess Cunegund, MS XIV A 17, fol. 9r, 1312, Národní knihovna České republiky, Praha. 


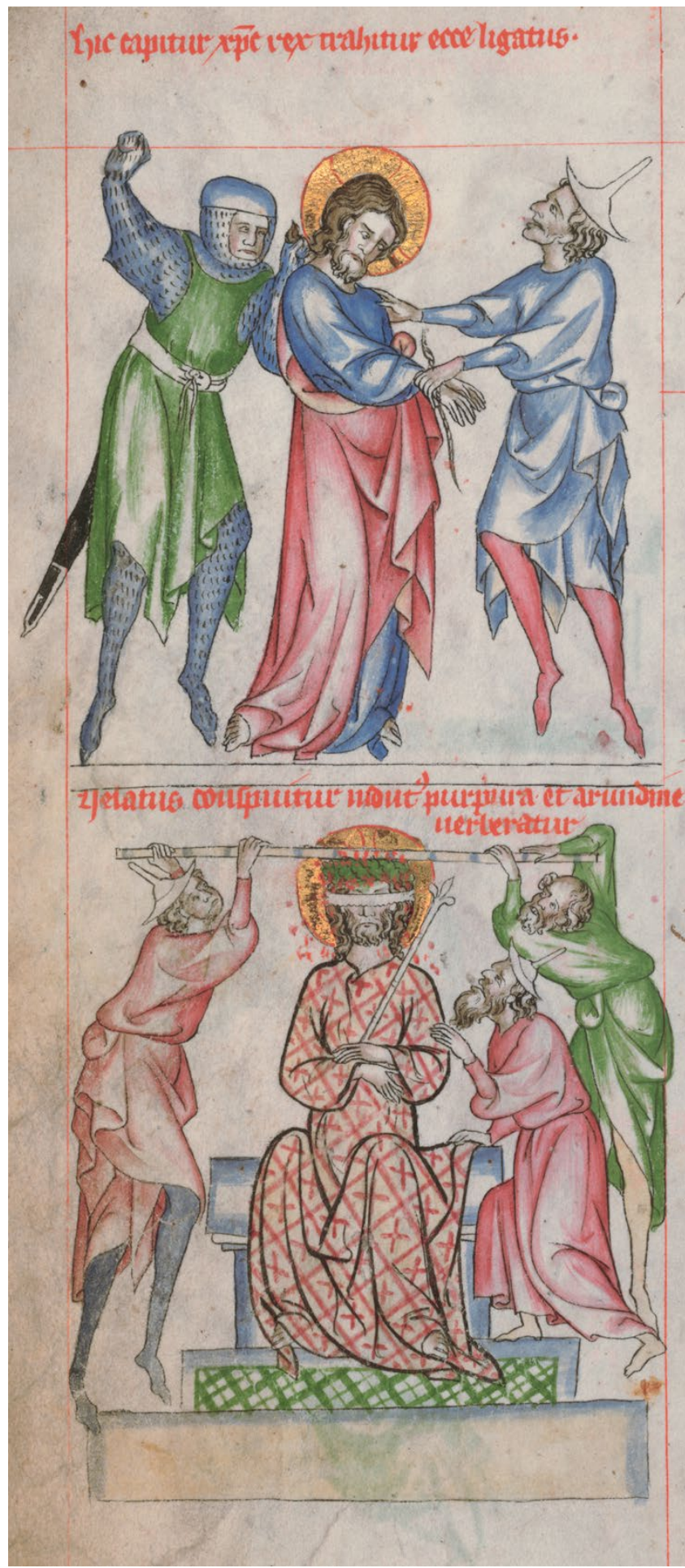

Figure 5. Tormenting of Christ / Mocking of Christ, Passional of Abbess Cunegund, MS XIV A 17, fol. 6v, 1312, Národní knihovna České republiky, Praha. 
with the Instruments of the Passion on fol. 10r. The fol. 6v soldier's raised and clenched fist does, however, correlate with the image of alapa - the slap, which figures boldly beside the cross on fol.10r. There, the hand is un-armoured and the fingers spread, nevertheless alapa embodies the multitude of bodily insults inflicted upon Christ by physical assault, including that depicted on fol. $6 \mathrm{v}$. In the same manner that the villain on fol. $3 \mathrm{v}$ embodies evil, so the soldier in the fol. $6 \mathrm{v}$ illustration embodies physical violence.

There are two further illustrations of soldiers in the first treatise of the Passional. Far from being aggressive, they appear as the diminutive unconscious forms of the sentinels set to guard Christ's tomb in the top illustration on fol. 9r of the Resurrection (Figures 4 and 7). ${ }^{27}$ Rather than being of solid flesh, they appear almost decorative, hovering against and merging with the tomb's marbled surface. Their portrayal is, I believe, particularly extraordinary for, despite being dressed as medieval men-at-arms and therefore representing Romans, they also exhibit distinctively Jewish attributes. Matthew, the only canonical gospel to mention tomb guards, describes the request made to Pontius Pilate by the Jewish 'chief priests and the Pharisees' for a sentry to be placed at the tomb to prevent the fulfilment of the Resurrection prophesy. ${ }^{28}$ Pilate agreed and responded by providing soldiers. Perhaps the image acknowledges this Jewish/Roman collaboration (which also recalls the similar collaboration illustrated in the image of Christ's arrest, on fol. $6 \mathrm{v}$ of the Passional, referred to above). ${ }^{29}$ I suggest that alternatively, and more persuasively, the artist may be using the fol. 9r sleeping soldiers as agents for an expression of contemporary enmity: altering their dress and emblazoning their shields with Jewish embellishments that directly link them with Jews, and thus picking them out for vilification.

The guard on the left of the fol. 9r image wears a style of hat known as pileum cornutum..$^{30}$ It is positioned, somewhat precariously, on top of his helmet, creating a highly unusual iconographic motif. ${ }^{31}$ Pilea cornuta were distinguished by their funnel-shaped crowns, and the universal wearing of these hats was imposed upon the Jews following a stipulation by the fourth Lateran Council in $1215 .{ }^{32}$ This soldier's shield displays the three balls that I believe to be the distinctive sign of a pawnbroker: a trade that was the province of Jews and Lombards in the Middle Ages. ${ }^{33}$ The shield of the Roman guard on the right is emblazoned with the image of a red pileum cornutum, also emphasising an

\footnotetext{
$27 \quad$ 'At the sight of him the guards shook with fear and lay like the dead,' Matthew 28:4, The New English Bible, New Testament. Oxford 1970, p. 54.

28 Matthew 27:62-66; The New English Bible, New Testament. Oxford 1970, p. 54.

29 John 18:12.

30 Horned skull-cap, see, STRICKLAND, D. H.: Saracens, p. 105.

31 A considerably later, but related, example, c.1380, is be found in the scene of the Resurrection on the Třebon altarpiece which includes a pileum cornutum-wearing guard (this is not, however, the hybrid hat-cum-helmet found on fol. 9r of the Passional) thus including Jews in the guarding of Christ's tomb. In an interesting additional detail, one of four seals depicted on the tomb (that nearest the seated guard) shows a shield displaying a Jew's hat surrounded by a fabricated 'Hebrew' script, see BRAUER, Barbara: The Třeboň Resurrection: Retrospection and Innovation. Umění 31, 1983, no. 2, pp. 150-158.

32 HEER, Friedrich: The Medieval World 1100-1300. London 1962, p. 255.

33 The origin of the three balls sign is possibly derived from the three, gold dowry-portions in St. Nicholas' legend, see, DE VORAGINE, Jacobus - STACE, Christopher (transl.): The Golden Legend. New York 1998, p. 11-15.
} 
association with Jews. ${ }^{34}$ These unusual iconographic devices were, I suggest, employed to convey a specifically negative message through the illustration of an heraldic allegiance. Paul Binski observed that in an illustration of Satan's armies in the Douce Apocalypse the arms of Gilbert de Clare feature on the pennants alongside the traditional three-frog heraldry of Satan himself. ${ }^{35}$ In the same manner, the Passional Master employs heraldic devices as a means to name and shame. This may be compared even more directly with another Resurrection illustration to be found in the De Lisle Psalter. ${ }^{36}$ The shield of a sleeping guard carries a blackened coat of arms of Scotland: the gules (red) devices are altered to sable (black), suggesting that it was painted at a time of particular English hostility towards the neighbouring Scots. ${ }^{37}$ The denigratory message conveyed against the Scots through the iconography is as clear here as is the hostility towards the Jews in the Passional example. The Passional 'soldier-others' on fol. 9r, like the De Lisle Psalter guards, may sleep but they simultaneously and incontrovertibly represent the 'evil enemy'.

\section{Jew}

Since Christ's Passion is the predominant theme of the first treatise in Abbess Cunegund's florilegium, it is of no surprise that Jews comprise the most conspicuous representatives of 'otherness'. There are no fewer than eleven negatively characterized images of Jews depicted between fols. $6 \mathrm{v}$ and $8 \mathrm{r}$, all with exaggerated facial features, hair and demeanour. In this, their representation conforms once again with an established artistic tradition. ${ }^{38}$ They are illustrated dressed in everyday apparel just as they would have appeared on contemporary city streets across medieval Europe. A strong Jewish trading presence was recorded in Prague as far back as 965 by an Arabian/Jewish merchant, Ibrahim ibn Jakub (d. 966). ${ }^{39}$ This early Jewish merchant class was then augmented by the Ostsiedlung: a surge of German emigrants across Europe, travelling from West to East. ${ }^{40}$ Their increased presence caused Otakar II to draw up a Jewish charter - 1254 and reintroduced in $1268-,{ }^{41}$ attaching Pope Innocent IV's Bull in an attempt to quell rumours of blood libel. ${ }^{42}$ (In 1251, Otakar II's father-in-law, King Bela IV of Hungary, had also created

\footnotetext{
34 The internationality of iconographic detail is demonstrated by the presence of a shield, bearing images of bearded Jews, wearing the characteristic pilea cornuta in the sculpted representation of the sleeping guards at Christ's Resurrection in the central west portal tympanum of Strasbourg Cathedral, c. 1320-1330: illustrated in STRICKLAND, D. H.: Saracens, p. 162.

35 Bodleian Library, Douce, MS 180, p. 87. BINSKI, Paul: Westminster Abbey and the Plantagenets : Kingship and the Representation of Power 1200-1400. New Haven - London 1995, p. 86.

36 British Library, Arundel, MS 83 II, fol. 133r.

37 Arguments concerning this suggestion are presented in detail in an unpublished doctoral thesis, VLČEK SCHURR, Jennifer: The Master of Abbess Cunegund's Passional : An Exploration of Style, Iconography and Nationality. University of Glasgow 2019, pp. 191-195.

38 See, STRICKLAND, D. H.: Saracens, pp. 95-155; LIPTON, S.: Dark Mirror, pp. 172-175.

39 VALLEY, Eli: The Great Jewish Cities of Central and Eastern Europe : A Travel Guide and Resource Book to Prague, Warsaw, Cracow and Budapest. Oxford 2005, p. 5.

40 BARTLETT, Robert: The Ostsiedlung. In: DITCHBURN, David - MACLEAN, Simon - MACKAY, Angus (eds.): Atlas of Medieval Europe. Oxford 2007, pp. 123-125.

41 See BLECHOVÁ, Lenka et al. (eds.): Prameny k dějinám Židů v Čechách a na Moravě / Sources for the History of Jews in Bohemia and Moravia. Praha 2015, no. 47, pp. 45-51; No. 51, pp. 56f.; No. 54, pp. 60f.

42 VALLEY, E.: The Great Jewish Cities, p. 66.
} 
such a charter having himself followed the example of similar statutes laid down by Fred-

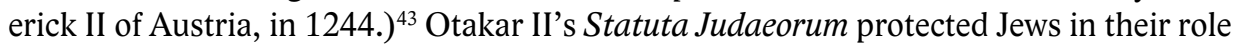
as usurers - an occupation considered sinful by Christians - and declared them to be servi camerae regiae. ${ }^{44} \mathrm{He}$ forbade the populace to attack Jews, their property, their synagogues or their cemeteries. ${ }^{45}$ This suggests that these were frequent occurrences. In return, the crown demanded of them high taxation which was to be paid directly to the king. ${ }^{46}$

Prague was home not only to merchant Jews but also to many eminent Jewish scholars and poets, a fact that may have softened the attitudes of some towards them. Included among members of this Jewish intelligentsia were the twelfth-century Tosafist and poet, Isaac ben Jacob ha-Lavan of Prague; the physician, Isaac ben Mordecai of Prague (Ribam); the poet, Abraham ben Azriel of Bohemia; and the great, thirteenth-century scholar, Rabbi Isaac ben Moses of Vienna (Or Zaru'a). ${ }^{47}$ Jits Van Straten notes that some forty words in staročeština - Old Czech - appear in Abraham ben Azriel's Arugat habosem, ${ }^{48}$ demonstrating close linguistic and cultural links between Jews and Czechs in medieval society. ${ }^{49}$ Relations appear to have deteriorated under the reign of Cunegund's brother, Wenceslas II, and in 1296 he held Jewish leaders to ransom in order to raise funds. ${ }^{50}$ Already complex and strained social tensions were further aggravated by the appalling 1298 Rintfleisch massacres that claimed the lives of thousands of German and Austrian Jews. ${ }^{51}$ Wenceslas II offered his Czech Jews some degree of protection but through extortion. ${ }^{52}$ Cunegund was absent from Prague between 1291-1302, at the court of Mazovia, and therefore not directly exposed to this unhappy interlude. Many Jews travelling eastwards across Europe were fleeing persecution: Jews were expelled from England in 1290, and from France in 1306, all contributing to the Ostsiedlung in the years directly leading up to the creation of the Passional. ${ }^{53}$ The text of this manuscript does not particularly malign Jews; ${ }^{54}$ indeed, they receive somewhat harsher treatment at the hands of the artist.

\footnotetext{
$43 \quad$ Ibid., p. 7.

44 The title 'servants of the king's chamber' was applied to Jews within the Holy Roman Empire by Frederick II in 1236 and was less benign than it might appear for it enabled exertion of judicial rights over the Jews, HERSCH, Philip: Anti-semitism 1096-1306. In: DITCHBURN, D. et al. (eds.): Atlas, pp. 180-182, at p. 180.

45 See, VALLEY, E.: The Great Jewish Cities, p. 7.

46 Ibid. p. 66.

47 Jewish Virtual Library. https://www.jewishvirtuallibrary.org/bohemia (viewed from 5th January 2016).

48 'Bed of spices,' a collection of liturgical poetry, see, VAN STRATEN, Jits: The Origin of Ashkenazi Jewry: The Controversy Unravelled. Berlin - New York 2011, p. 121.

49 Ibid. pp. 120-121. On the west Slavic Knaanic language see BLAHA, Ondřej - DITTMANN, Robert Dittmann - ULIČNÁ, Lenka (eds.): Knaanic Language : Structure and Historical Background. Praha 2013; BLAHA, Ondřej - DITTMANN, Robert - KOMÁREK, Karel (eds.): Kenaanské glosy ve středověkých hebrejských rukopisech $s$ vazbou na české země / Knaanic Glosses in Medieval Hebrew Manuscripts associated with the Czech Lands. Praha 2015.

50 VALLEY, E.: The Great Jewish Cities, p. 8.

51 FIALA, Z. (ed.) - HEŘMANSKÝ, F. (transl.): Kronika, pp. 168-169.

52 Ibid., p. 168.

53 HERSCH, P.: Anti-semitism, p. 182; BARTLETT, R.: The Ostsiedlung, pp. 123-125.

54 Antisemitism expressed within the Passional is briefly discussed in SOUKUP, Daniel: Mor, masakr, Maria : Protižidovské aspekty pozdně středověké zbožnosti / Plague, massacre, Mary : Anti-Jewish Aspects of Late Medieval Piety. In: KUBINOVA, Kateřina et al. (eds.): Karel IV. a Emauzy: Liturgie - text - obraz / Charles IV and the Emmaus Monastery: Liturgy - text - picture. Praha 2017, pp. 266-281.
} 


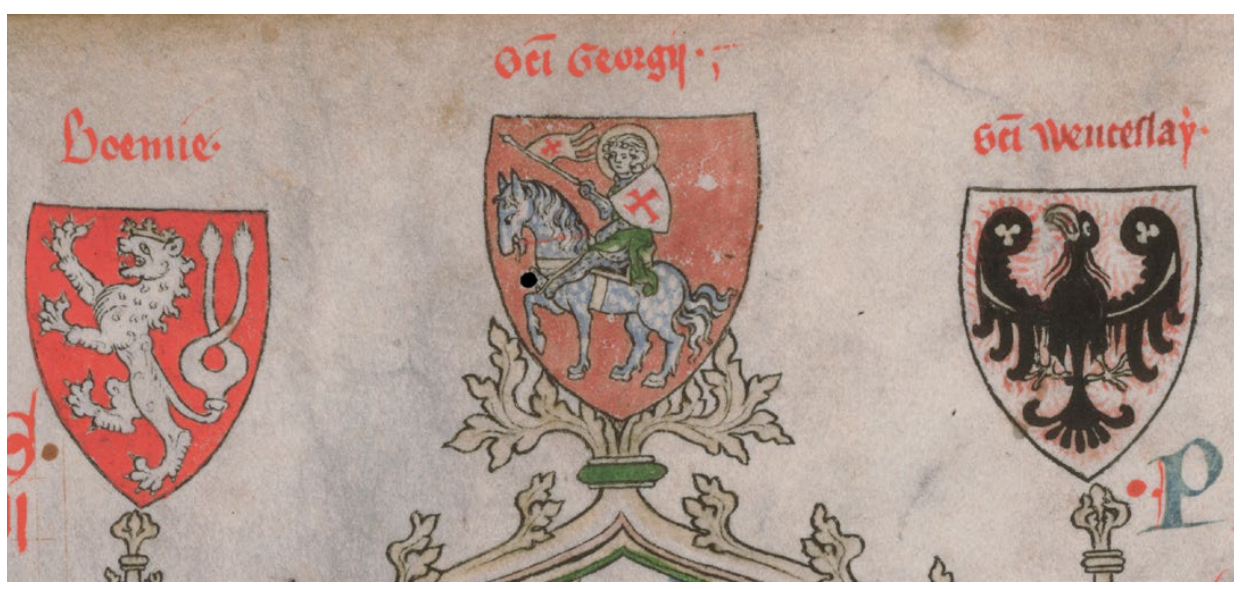

Figure 6. Detail. Heraldic Shields of Bohemia, St. George, St. Wenceslas, Dedication Illustration, Passional of Abbess Cunegund, MS XIV A 17, fol. 1v, 1312, Národní knihovna České republiky, Praha.

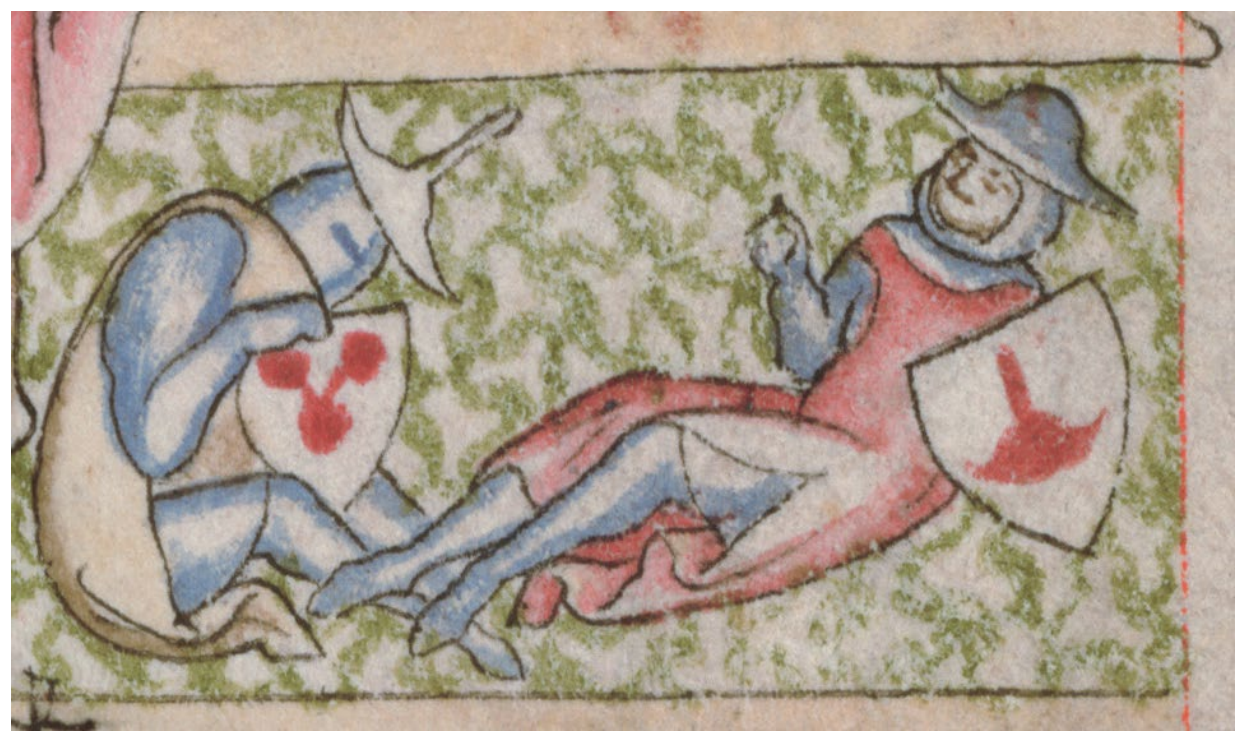

Figure 7. Detail. Sleeping Guards, Resurrection, Passional of Abbess Cunegund, MS XIV A 17, fol. 9r, 1312, Národní knihovna České republiky, Praha. 
Prague Jews, as across the rest of Europe, were confined to their city quarter at night, ${ }^{55}$ and during the day were compelled to wear identifying badges and pilea cornuta. ${ }^{56}$ This distinctive headwear marked them out as easy targets for abuse, and Strickland notes how its over-emphasised and exaggerated depiction was particularly insulting. ${ }^{57}$ In the Passional, pilea cornuta are highly visible, featuring prominently among the aggressors in Christ's Passion. In this context, these distinctive hats - accompanied by the representation of long straggly hair, shaggy beards, and exaggerated facial-features and postures - signal to the reader that these are evil-doing Jews. The Passional representations adhere to thirteenth-century stereotypical propagandistic iconographical norms. ${ }^{58}$ Such caricatured imaging also served to reinforce an already deeply embedded perception of a corporate Jewish responsibility for Christ's death. ${ }^{59}$

The Benedictine theologian, the Venerable Bede (672-735), judged Christ's wounds to have been preserved that he might, show them to the Jews at the Last Judgement that they may see how much He suffered through them..$^{60}$ I note that the perceived universal guilt of Jews also finds expression in the prayers that originally closed the first treatise of the Benedictine Abbess Cunegund's florilegium. These prayers, together with the final words of Colda's treatise, were written on a now lost folio which would have faced the Andachtsbild of the Man of Sorrows with the Instruments of the Passion on today's fol. $10 \mathrm{r} .{ }^{61}$ The reference in one of the prayers to a cruel verbal attack on the dying Christ appears to implicate the entire Jewish people:

Christ Jesu am Creutz hangest...
Angebackt mit rauchen worten
Von den Juden harten Volck
Erlöß uns von ihren Folg. ${ }^{62}$

In a similar vein, in the Passional's second treatise, which comprises the text and illustrations of a lament, ${ }^{63}$ the Virgin Mary beseeches, Conpatimi/ni igitur michi et miseremini

$55 \quad$ BURTON, Richard: Prague : A Cultural and Literary History. Oxford 2003, p. 55.

56 Enforced many centuries earlier in Moslem countries HOOD, John Y. B.: Aquinas and the Jews. Philadelphia 1995, p. 32; see STRICKLAND, D. H.: Saracens, p. 105.

57 STRICKLAND, D. H.: Saracens, p. 105.

58 BALE, Anthony: The Jew in the Medieval Book. Cambridge 2006, p. 157. For further reading on the complex subject of anti-Jewish iconography and medieval Jewish dress code: in the Bohemian context see REITINGER, Lukáš - SOUKUP, Daniel: The Krumlov Liber Depictus : On its Creation and Depiction of Jews. Judaica Bohemiae 50, 2015, no. 2, pp. 5-44, esp. 20-23; and in a wider context, LIPTON, Sara: Dark Mirror: The Medieval Origins of Anti-Jewish Iconography. New York 2014, pp. 16-45; BAUMGARTEN, Elisheva, Practicing Piety in Medieval Ashkenaz: Men, Women, and Everyday Religious Observance. Philadelphia 2014, pp. 149-178; METZGER, Thérèse - METZGER, Mendel: Jewish Life in the Middle Ages: Illuminated Hebrew Manuscripts of the Thirteenth to the Sixteenth Centuries. New York 1982, pp. 115-124.

59 JORDAN, William Chester: The Last Torment of Christ : An Image of the Jews in Ancient and Medieval Exegesis, Art and Drama. The Jewish Quarterly Review 1/2, July-October 1987, New Series 78, pp. 21-47, at p. 37.

60 Quoted by SCHILLER, G.: Iconography II/2, p. 188.

${ }^{61}$ A late seventeenth-/early eighteenth-century German translation of the Passional text includes these prayers preserved in a slim volume held in Prague. NKČR, MS XVI E 12, fols. 20v-24r.

62 Christ Jesus you hang upon the cross...| Attacked with rough words |By the harsh Jewish people | Free us from their consequences, author's translation of NKČR, MS XVI E 12, fols. 23v-24r, transcribed by TOUSSAINT, G.: Das Passional, p. 196.

63 Second treatise, 1312-1314, composed by unknown author, written up by Beneš, canon of the Basilica of St George, illustrated by the Master of the Passional, NKČR, MS XIV A 17, fols. 11r-17v. 
mei saltem/vos Christani amici mei quia inaudita exer/cuerunt ludibria crudelissimi iudei indilecto/filio uteri mei. ${ }^{64}$ She further refers to, [... I Iudeorum perfidia/immo crudelis sevicia $[\ldots]^{65}$ It should be noted how a sharp distinction is drawn between generous-hearted Christians and cruel Jews, playing once again into the perceptions of the age.

The Jew as law-enforcer - described in John's gospel and pictured in the upper image on fol. 6v (Figure 5) - has been briefly mentioned. A closer examination of the fol. 6v illustration reveals a typically caricatured illustration of a Jew: his hair hangs in distinctive ringlets; he is shown in profile; ${ }^{66}$ he displays a prominent chin and large nose - a familiar artistic prompt. ${ }^{67}$ The corner of his mouth is retracted into an unattractive leer and his jaw drops in an unsightly gape as he expectorates on his prisoner. This would remind the medieval onlooker of the startling belief, as described by Anthony Bale, that the mouth of the Christian was reserved for hymnody and receiving the sacrament, and the mouth of the Jew was associated with Judas' kiss and spitting on Christ. ${ }^{68}$ The figure is unmistakably highlighted as a Jew and an antagonist. I believe that the artist, by depicting him in the act of spitting on Christ, illustrates Colda's deliberately shocking account of Christ's spittle-covered face and his humiliation by the Jews : Ecce audistis dilectissimi quota pro nostris iniquitatibus filius dei / pertulit dum despectus propter alapas factus vultum sub spu/tis iudeorum abscondit. ${ }^{69}$ These words anticipate an unfortunate anti-Jewish simile which appears in the second treatise of the Passional: Intuemini quia caput eius / plenum est rore et cincinni eius guttis noc/tium id est nocturnis sputis Iudeorum. ${ }^{70}$ Just as the other identifiable Jews on fols. $6 \mathrm{v}$ and $7 \mathrm{r}$ (Figures 5 and 8) - all engaged in active, cruel acts of torture -, the Jew in fol. 6v's uppermost illustration is depicted in the dress of a medieval working man: shoeless, in knitted hose, robes pulled in at the sleeves and, together with two of the other Jews represented, with his tunic-hem gathered and tucked into his belt for ease of movement. ${ }^{71}$ Both the Jew and the soldier on fol. $6 \mathrm{v}$ have one foot slightly raised as though hopping on the spot. This curious depiction of nervously energetic exertion is, I suggest, yet another indicator of ill-doing and/or Jewishness. (The only comparable image exhibiting this very specific pose, where one heel is higher than the other and the knee is demonstrably bent, is Christ in the scene of the Flagellation. Here, indeed, he has every reason for agitation). This attitude is recognisable in several other of the images of Jews in the Passional, as shall be demonstrated, and is quite unlike the purposeful striding step of, for example, Christ in the illustration of the Harrowing of Hell, the middle image on fol. 9r (Figure 4) which, in contrast, conveys not only movement but also the fulfilment of good intent.

The lower fol. 6v image of the Mocking of Christ, employs largely conventional iconography (Figure 5). Christ is robed, blind-folded, enthroned and crowned with thorns.

\footnotetext{
64 Therefore, have compassion and take pity on me at least you Christians, my friends, for the exceptional mockery practiced by the utterly cruel Jews against the beloved son of my womb. NKČR, MS XIV A 17, fol. 11r, lines 19-23.

$65[\ldots]$ the treachery, indeed the cruel ruthlessness, of the Jews [...]. Ibid., fol. 11v, lines 25-26.

66 The iconographic significance of this as signaling a malefactor has already been noted.

67 STRICKLAND, D. H.: Saracens, pp. 77-78.

68 BALE, A.: The Jew, p. 152.

69 Behold, beloved ones, you heard how many things the Son of God endured for our sins, whilst he was made contemptible by the assaults, his face was obscured beneath the spittle of Jews. NKČR, MS XIV A 17, fol. 7r, lines 3-5.

70 Look, his [Christ's] whole head and his locks of hair are full of dew and night droplets; that is the night-time spittle of Jews. NKČR, MS XIV A 17, fol. 11r, lines 23-25.

71 SCOTT, Margaret: Fashion in the Middle Ages. Los Angeles 2011, p. 78.
} 


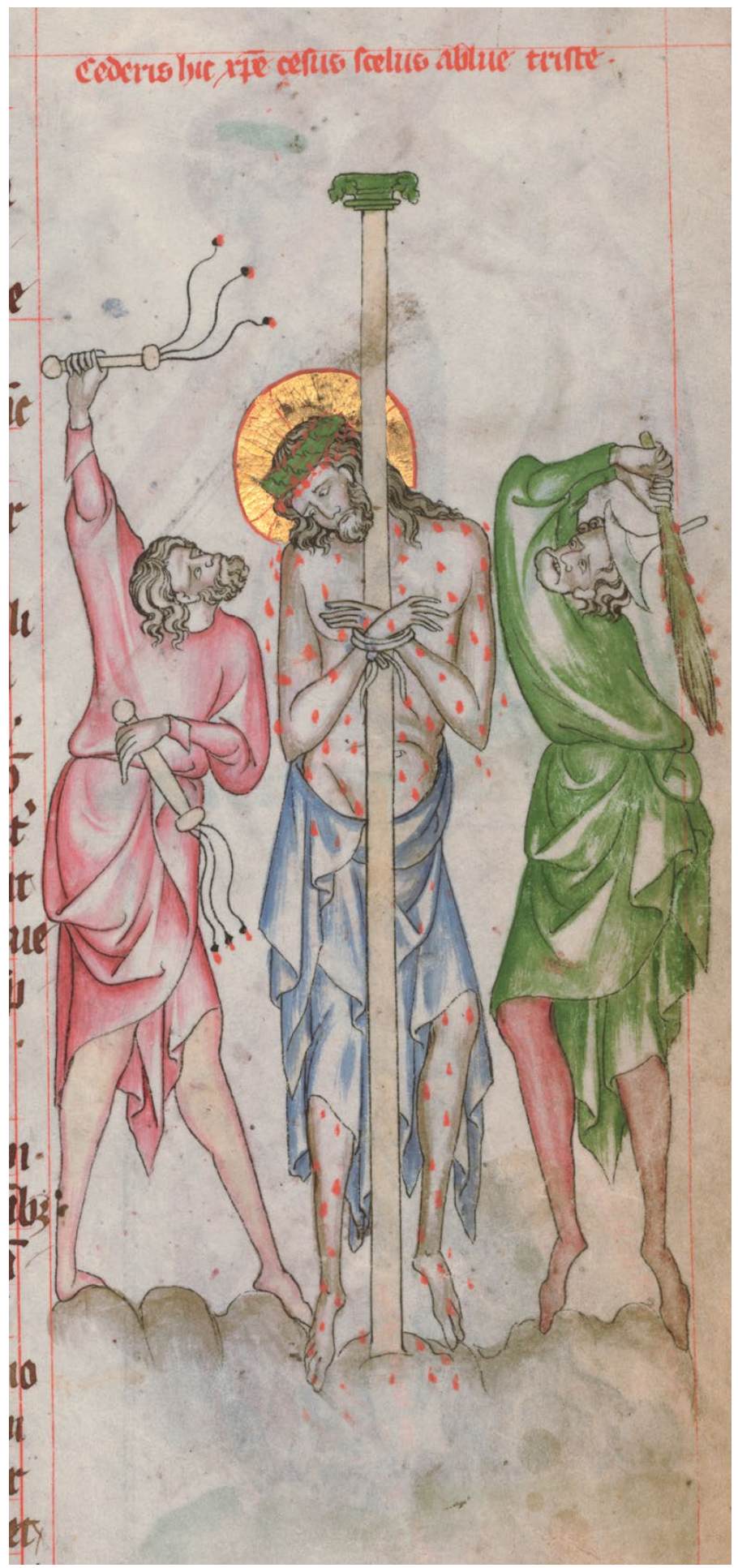

Figure 8. Flagellation of Christ, Passional of Abbess Cunegund, MS XIV A 17, fol. 7r, 1312, Národní knihovna České republiky, Praha. 


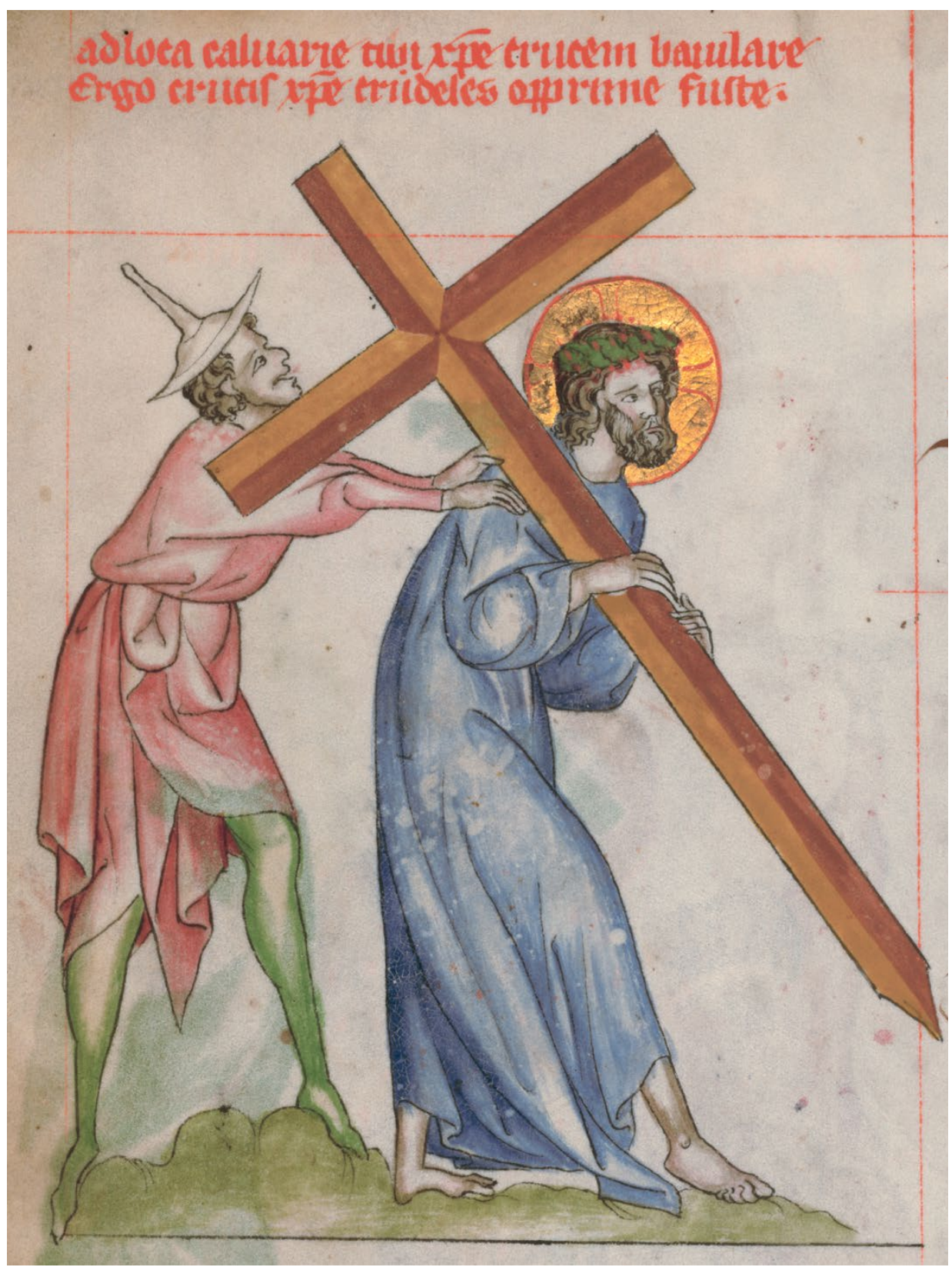

Figure 9. Christ bearing the Cross, Passional of Abbess Cunegund, MS XIV A 17, fol. 7v, 1312, Národní knihovna České republiky, Praha. 
Mark's gospel describes how those who mocked Christ, beat him about the head with a cane and spat upon him, and then knelt and paid mock homage to him. ${ }^{72}$ Although the perpetrators are identified in the gospel as soldiers, the Passional artist chose to illustrate them as Jews. In the previous gospel chapter, Mark described how the high-priest's men began to spit on him, blind-folded him, and struck him with their fists. ${ }^{73}$ In this image, the artist has amalgamated the two violent incidents. One of the aggressors is portrayed as an elderly kneeling man with a long beard; his tunic is not tucked up, but the caricatured Jewish profile is instantly recognisable. As the rod presses the crown of thorns down upon Christ's head, this spitting Jew parodies reverence as he genuflects, grimaces and expectorates. Interestingly, the character leaning over him and holding the rod is not depicted wearing a pileum cornutum. He is, however, identifiable as a Jew by his shaggy beard and the ringlets falling over his ears. ${ }^{74}$ These latter appear all the more conspicuous in contrast to his balding pate.

I note that, like his other Jewish companions, his head is strongly tilted back. This curiously distorted posture is frequently employed in the iconography of Jews where the head is held, as described by William Chester Jordan, 'parallel to the sky'. ${ }^{75} \mathrm{He}$ observes a particular association of this posture with portrayals of the sponge-bearer, Stephaton (his traditional name, although it is not mentioned in the bible). ${ }^{76}$ The Passional's Stephaton in the fol. 8r Crucifixion does not disappoint (Figure 11) as he adopts this distorted pose and lifts his over-long rod and sponge to Christ's lips. All the Jews in the illustrations on fols. $6 \mathrm{v}$ and $7 \mathrm{r}$ crane their heads backwards, but none more so than the menacingly grotesque figures thrashing Christ in the fol. 7r image of the Flagellation (Figure 8). Once again, one of these torturers is bare-headed but his exaggerated tilted head-posture, together with his beard and ringleted hair, immediately reveals his Jewish nationality to the cognisant viewer. On the double-spread of fol. 6v and 7r (Figures 5 and 8), Christ is set upon by seven 'others', all in contemporary, medieval dress. Six are identifiable as Jews, and one as a soldier.

Overleaf, on fol. 7v (Figure 9), the rubric title above the upper image reads, Ad loca calvarie tibi Christe crucem baiulare / ergo crucis Christe crudeles opprime fuste. ${ }^{77}$ The Passional Master depicts a meek Christ, pushed and hurried-along, rather than assisted, by Simon of Cyrene. This illustration may be usefully compared with an example on an English embroidered orphrey from the same period (Figure 10). This fine work of opus anglicanum portrays Simon with the tousled hair of the ill-doer. Recognisable in both images is the, now familiar, highly caricatured profile - beetle-browed, with prominent nose and chin, and gaping grimace; the darker complexion of the orphrey malefactor may, however, signal other racial allusions. Both the embroiderer and the Master of

\footnotetext{
72 Mark 15:19. The New English Bible, p. 87.

73 Mark 14:65. Ibid., p. 85.

74 Hair falling in individual ringlets around the head feature quite consistently in the Passional images of Jews, leading to a reasonable assumption that this was based on the artist's observations of contemporary Prague Jews. The clearest example of this is in the depiction of the Jew in fol. 6v's upper scene.

75 JORDAN, W. C.: The Last Torment, p. 34.

76 Ibid., p. 126.

77 It is your task, Christ, to carry the burden of the cross to the place of Calvary / therefore, Christ, overpower the cruel [ones] with the rod of the cross. rubric title. NKČR, MS XIV A 17, fol. 7v.
} 


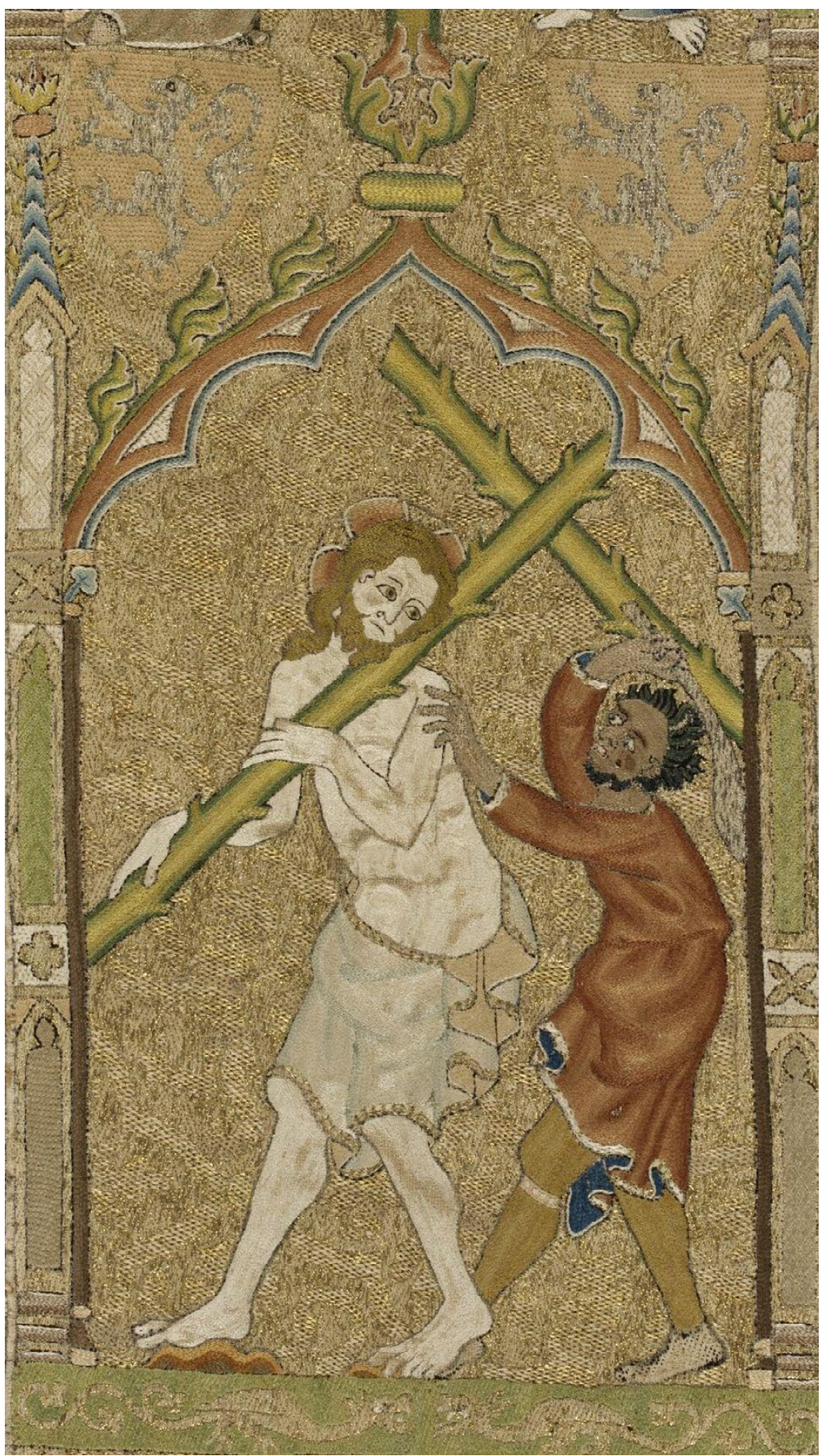

Figure 10. Detail. Christ bearing the Cross, Marnhull (or Wokyndon) Orphrey, opus anglicanum, inv. no. T31-19 36, Victoria and Albert Museum, London. [OVictoria and Albert Museum, London] 
the Passional have succeeded in creating an unappealing image. ${ }^{78}$ I suggest that in the Passional's fol. 7v illustration - through Simon's posture as he appears to shove Christ and his Cross, and by the sharp red tongue that flicks out of his open mouth - the artist is evoking the account given in the highly influential Meditations on the Life of Christ of how Christ, is led and hurried and saturated with taunts. ${ }^{79}$ This Jew's robes are once again gathered up, demonstrating that he is a working man. The artist has furnished him with an over-large pileum cornutum, its size amplifying the negative implications of the image.$^{80}$ In the Passional image, Simon of Cyrene is clearly intended to represent one of the 'cruel' ones, referred to in the illustration's rubric title, and who is be subdued by the power of the Cross. It will be recalled that in the Passional's second treatise, the lament of the Virgin Mary, the adjective 'cruel' was applied to the Jews on fol. 11r, line 22, and again on fol. $11 \mathrm{v}$, line 26.

Stephaton, the sponge-bearer, is afforded a prominent position on the next page: fol. 8r's representation of the Crucifixion (Figure 11). His face is presented to the viewer in profile, and his head is set 'parallel to the sky'. Another of Jordan's observations is also satisfied: that Stephaton is usually depicted holding the rod-shaft in his right hand and bucket in his left. ${ }^{81}$ The depiction of an extremely long rod-shaft in this image - allocating the bearer an ignominious position at the bottom of the scene - may be seen as particularly pejorative. Seated just above and to the right of Stephaton, at the foot of the cross, the artist has prominently depicted a group of three figures. John's gospel describes four soldiers; ${ }^{82}$ the other gospels are unspecific. ${ }^{83}$ The artist, however, has depicted Jews presumably representing members of the Sanhedrin. ${ }^{84}$ They are shown drawing lots: an activity, I would suggest, not far removed from the practices of bartering and usury for which Jews were required and renowned. ${ }^{85}$ The accompanying fol. $8 \mathrm{r}$ rubric not only recalls John's account - We must not tear this; let us toss for it ${ }^{86}$ - but urgently includes the group of Jews in the drama by thus providing them with direct speech. Two of these Jews have shaggy, grey beards and wear pilea cornuta. The third, whose brown hair is tamed and beard neatly styled, wears a broad, miniver-trimmed collar with a matching hybrid hat, reminiscent of that worn by Christ, the nobleman, in the final two images on fol. $3 \mathrm{v}$ (Figure 1). The headdress is that of a wise councillor except that on fol. $8 \mathrm{r}$ the artist has crowned it with a pink pileum cornutum. Once again, as with the sleeping guard on fol. 9r (Figure 7), the Master of the Passional has fused two specific styles of hat to express the wearers' identity, and to convey their allegiances to the viewer. Flashes of

\footnotetext{
78 Simon was pressed to carry Christ's cross, Matthew 27: 32; Mark 15: 21; Luke 23: 26. NKČR, MS XIII E 14c.

80 The phenomenon noted by STRICKLAND, D. H.: Saracens, p. 105.

81 JORDAN, W. C.: The Last Torment, p. 34.

82 John 19:23.

83 Matthew 27:35-36; Mark 15: 24; Luke 23:34.

84 John 19:23-24.

85 HOOD, J. Y. B.: Aquinas, pp. 23-25.

86 John 19:24, The New English Bible, p. 185.
}

79 PSEUDO-BONAVENTURA: Meditationes vitae Christi. In: RAGUSA, Isa - GREEN, Rosalie B. (eds.): $M e-$ ditations on the Life of Christ : An Illustrated Manuscript of the Fourteenth Century. Princeton 1977, p. 331. Vilikovský refers to an unidentified volume of Pseudo-Bonaventura, Meditationes Vitae Christi in Cunegund's library. VILIKOVSKÝ, Jan: Písemnictví českého stréedověku / Czech Medieval Literature. Praha 1948, p. 27. Writings of Pseudo-Bonaventura are included in the 1303 florilegium gifted by Cunegund to St. George's Convent, Prague. 
miniver peep from the lining of this conspicuously wealthy Jew's outer robe. ${ }^{87}$ Although not a 'positive' image, being decisively implicated in Christ's Passion, this Jew's fur trimmings intimate high rank and I believe that the image appears to acknowledge a degree of respect afforded to some elite Jews.

In the first Passional treatise, the Crucifixion is illustrated twice: fol. $8 \mathrm{r}$ depicts a dying Christ (Figure 11), whilst overleaf on fol. $8 \mathrm{v}$ his body hangs limp and lifeless (Figure 12). In the second image on fol. $8 \mathrm{v}$, the Deposition, a small individual, pulling the nail out of Christ's left hand, is depicted with his face parallel to the arm of the cross, adopting the characteristically twisted stance discussed above. He also wears the Jews' distinctive, conical hat. Once again, even in this minute depiction, the artist captures the agitated bearing of the Jew who appears as if dancing upon the ladder. This figure is of particular interest for, despite these negative identifiers, he actually performs a positive service by withdrawing the nail. He may be seen as belonging to what I categorize as a sub-group of 'positive others', also represented by Joseph of Arimathea who appears in both the Deposition and Entombment illustrations on fol. 8v. Joseph's medieval clothing contrasts the 'biblical dress' of the principal characters, including Christ, Mary and the apostles, as he is marked out as Jew. In the Deposition, Joseph's head is also thrown back, 'parallel to the sky,' as he goes cheek to cheek with the dead Christ, whom he lowers from the cross. But it is Joseph of Arimathea's headdress that I note as the most significant pointer.

The artist appears to highlight the 'positive Jew' by replacing the pileum cornutum with another type of headwear used to identify Jews in the Middle Ages: the soft Phrygian felt cap. ${ }^{88}$ The Passional's 'positive Jews' are important yet marginal protagonists, the latter indicated by their contemporary dress. The exceptions to this rule are the patriarchs and the central figure of the group of prophets, illustrated on fol. 22v of Colda's 1314 treatise on the Heavenly Mansions (Figure 13). ${ }^{89}$ These illustrious figures from the Old Testament are awarded 'biblical dress', however five of them are depicted by the artist as wearing Phrygian caps, signifying both their Jewishness and their positive status. In the fol. $8 \mathrm{v}$ Deposition illustration, Joseph of Arimathea is shown wearing a red felt hat; in the lower image of the Entombment, it is swapped for a blue one, perhaps signifying the passage of time.

St. Joseph, like his namesake Joseph of Arimathea, is pictured in the fol. 5v Nativity wearing a red, soft, Phrygian-form of Jewish hat (Figure 14). (Note here, the shepherd's craning neck, his face 'parallel to the sky', identifies him as a Jew despite the fact that he wears a hood rather than a felt cap). In the scene of the Circumcision on fol. $6 \mathrm{r}$, Joseph's cap is complemented by a medieval, caped gown known as a houce (Figure 15)..$^{90}$ This same, high-status garment is worn by another benign Jewish character, King David, on fol. $17 \mathrm{v}$, at the end of the second treatise (Figure 16). In this image of the Coronation of the Virgin, King David is pictured beneath a throne, the cape of his houce tossed back to free his hands for harp-playing. He makes a further and considerably more

\footnotetext{
$87 \quad$ Miniver, indicated in painting by distinctive blue and white patterning, was considered a particularly high-status fur from the grey and white winter coat of squirrels. SCOTT, M.: Fashion, p. 15.

88 See STRICKLAND, D. H.: Saracens, p. 105.

89 Third treatise, 1314, composed by Colda of Colditz, written up by Beneš, canon of the Basilica of St George, illustrated by the Master of the Passional. NKČR, MS XIV A 17, fols. 18r-29v.

90 A late thirteenth-/early fourteenth-century high-status outer garment with elbow-length cape sleeves, SCOTT, M.: Medieval Dress, pp. 79 and 88.
} 


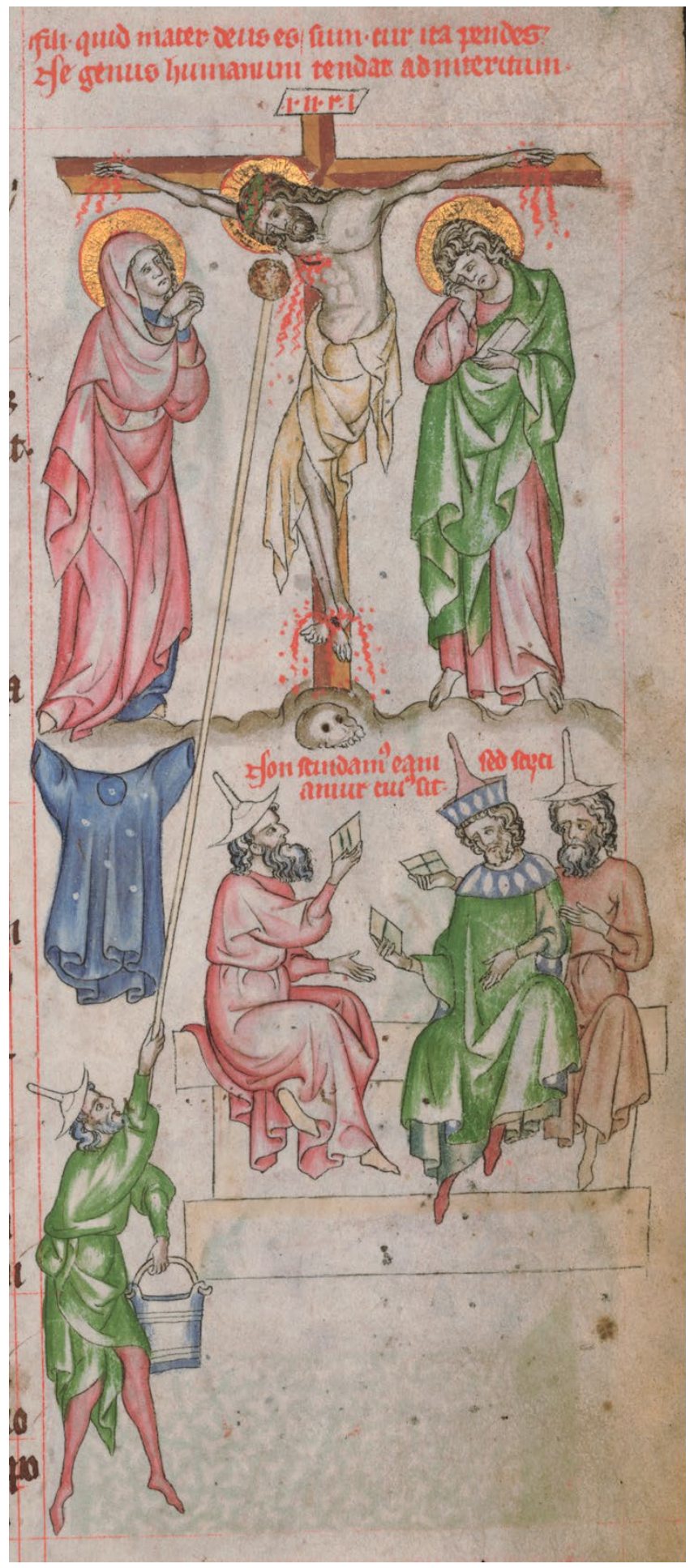

Figure 11. Crucifixion, Passional of Abbess

Cunegund, MS XIV A 17, fol. 8r, 1312, Národní knihovna České republiky, Praha. 


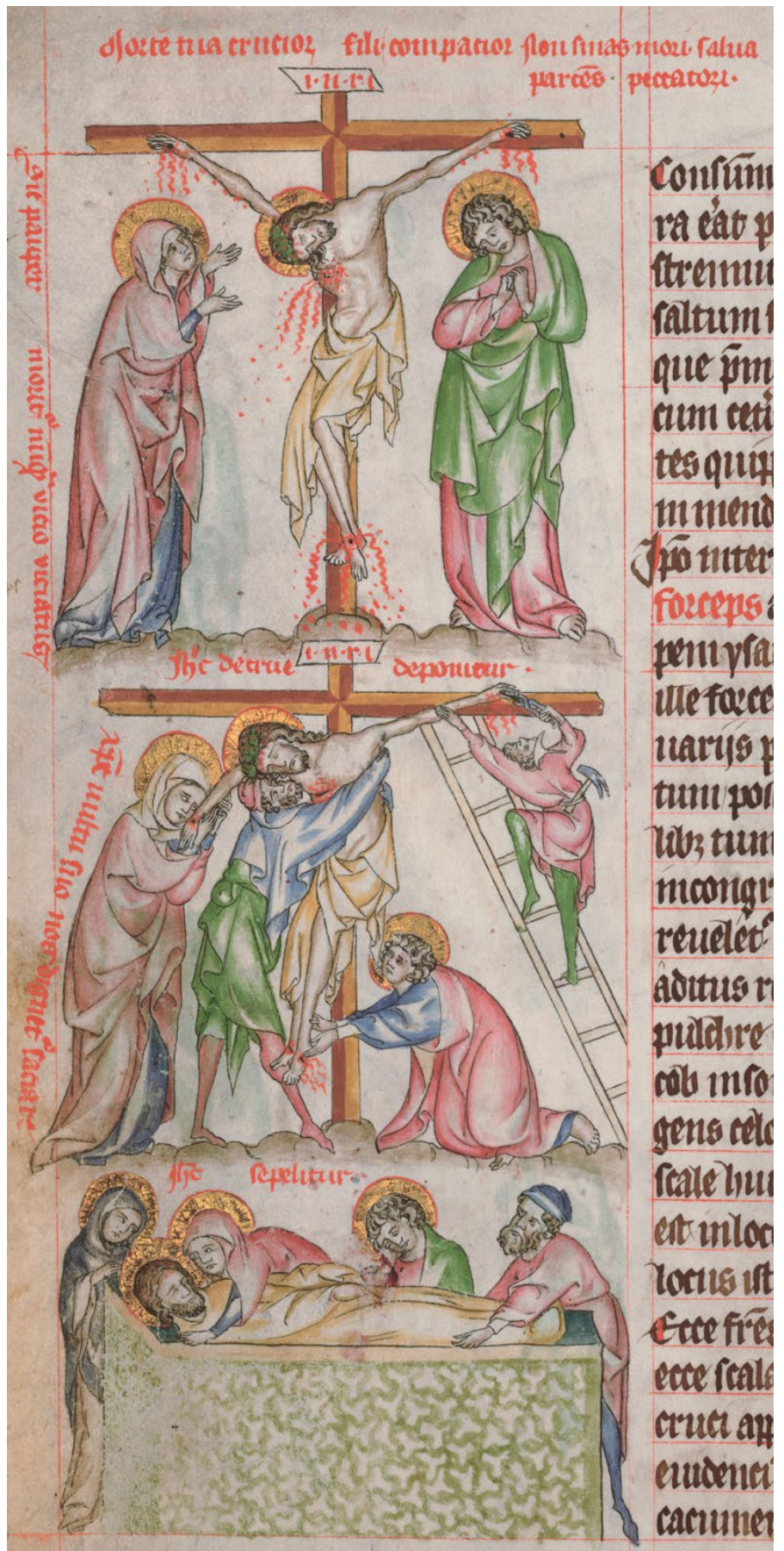

xpe mellece tion nog recteamue vita.
Figure 12. Crucifixion, Passional of Abbess Cunegund, MS XIV A 17, fol. 8v, 1312, Národní knihovna České republiky, Praha. 
dramatic appearance in what I interpret as the guise of a contemporary Czech King in the scene of Resurrection on fol. 9r (Figure 4). He is presented as a large and arresting personage, dressed in a gilded, fleuron crown and high-status miniver-lined robes. ${ }^{91}$ The upper opening-edge of King David's heavy mantle is trimmed with what are described by Margaret Scott as crucial identifying elements, the 'tongues' (languettes). ${ }^{92}$ These small, brown, overlapping pelts - possibly of strandling, which is the squirrel's rust-red, autumn coat ${ }^{93}$ - feature on several Czech royal family tombstones, including that of Abbess Cunegund herself, and are also illustrated in the images of the young royal couple on fol. $3 \mathrm{v}$ (Figure 1). ${ }^{94}$ Strickland notes that, especially positive treatment is given to certain important figures, such as David, seen as typological models for Christ and contemporary kings. ${ }^{95}$ I suggest that the fol. 9r image (Figure 4) may thus be read as highlighting the sacra stirps (sacred lineage) of the Premyslid kings, drawing a direct link between King David - Jesus' illustrious ancestor who is here dressed as a Czech King - and the Premyslid rulers of Bohemia. King David's command, following the line of his harp in rubric, calls for Christ's Resurrection: Exsurge mea gloria. ${ }^{96}$ These words echo those repeated again and again in Colda's accompanying text. Fol. 9r line 15 launches into an invocation which brings the instructive treatise towards its close with a triumphal and redemptive cry: exsurge (rise up) is repeated six times in four lines, and in the last line the resurrection is pronounced complete in surrexit (he arose).${ }^{97} \mathrm{I}$ consider these words germane in also summoning up a longed-for Premyslid dynastic revival: the male line was extinguished with the assassination of the sixteen-year-old King Wenceslas III, 4 August $1306 .{ }^{98}$ One of the primary duties of Cunegund, as a Premyslid princess and Benedictine abbess, would have been to pray for the future prosperity of her dynasty and, through memoria, for the souls of her forbears. ${ }^{99}$ This is clearly demonstrated by a prayer within her personal breviary, invoking the memory of her closest family members: 'In the most sacred presence of your body and blood Lord Jesus Christ, I commend to you your servants and handmaidens, Wenceslas, Agnes, Přemysl, Cunegund and all my near relations and the closely associated religious community, living and dead.' ${ }^{100}$ The evidence

$91 \quad$ Fleuron crowns, as the name suggests, feature stylized flower forms and were favoured by the French royalty, BINSKI, P.: Westminster Abbey, p. 110. They were also worn by contemporary Czech royalty.

92 SCOTT, M.: Medieval Dress, p. 110.

93 Idem: Fashion, p. 26.

94 In 1352, the father of Charles V of France possessed a houce - the same garment worn by King David in his fol. $17 \mathrm{v}$ portrait - made from 440 squirrel-abdomen pelts and trimmed with six languettes. SCOTT, M.: Medieval Dress, p. 110.

95 STRICKLAND, D. H.: Saracens, p. 97.

96 'Rise up, my glory,' rubric title, fol. 9v.

97 exsurge nunc [...] Exsurge gloria mea; exur/ge [sic] psalterium et cithara [...] respondet in psal/mo "exsurgam dilucio". Exsurge igitur domine; exsurge in adiuto/rium sponsae tuae. Surrexit [...]. NKČR, MS XIV A 17, fol. 9r, lines 15-18.

98 FIALA, Z. (ed.) - HEŘMANSKÝ, F. (transl.): Kronika, pp. 251-258.

99 On the obligation of memoria see HAMBURGER, Jeffrey - MARX, Petra - MARTI, Susan: The Time of the Orders 1200-1500 : An Introduction. In: HAMBURGER, Jeffrey - MARTI, Susan (eds.): Crown and Veil : Female Monasticism from the Fifth Century to the Fifteenth Centuries. New York 2008, pp. 41-75, at p. 62.

100 In praesentia sanctissimi / corporis et sanguinis tui domi/ne Ihesu Christe. Commendo tibi / famulos et famulas tuas /Wencezlaum. Agnetem. Pre/miszlium. Chunnegundim / et omnes michi consangui//nitate propinquos et fraternitate / coniunctos vivos et defunctos. NKČR, MS VII G 17d, fol. 151v l.8-152r 1.2. 


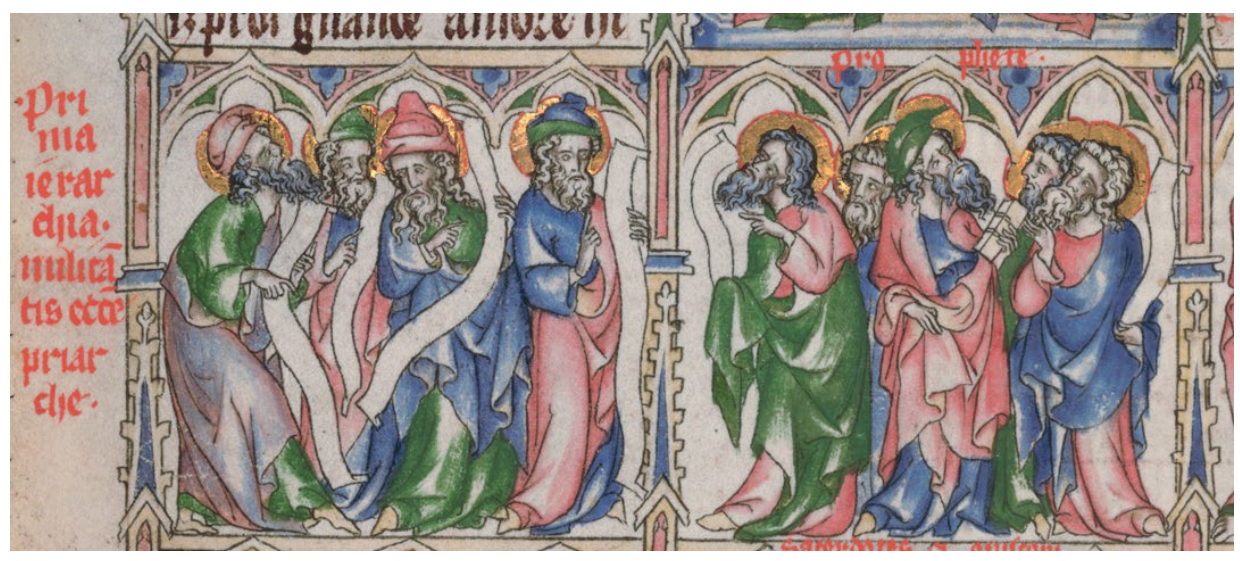

Figure 13. Detail. Patriarchs and Prophets, Heavenly Mansions, Passional of Abbess Cunegund, MS XIV A 17, fol. 22v, 1312, Národní knihovna České republiky, Praha.

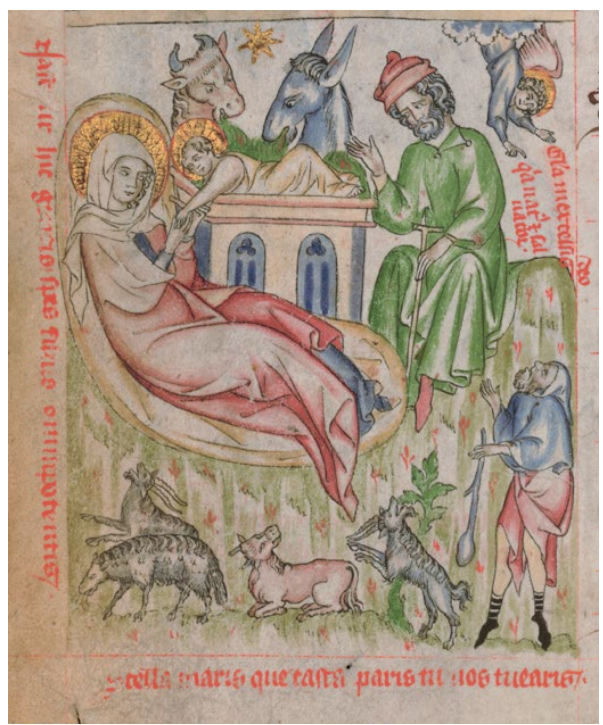

Figure 14. Nativity, Passional of Abbess Cunegund, MS XIV A 17, fol. 5v, 1312, Národní knihovna České republiky, Praha.

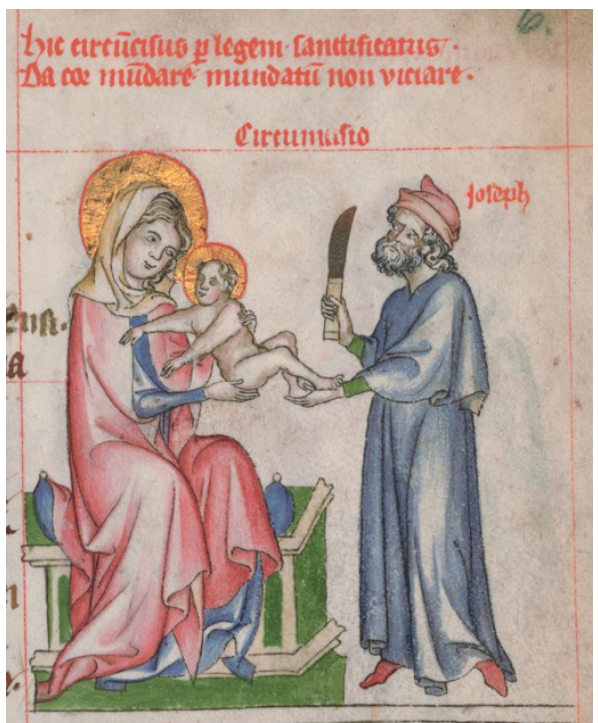

Figure 15. Circumcision, Passional of Abbess Cunegund, MS XIV A 17, fol. 6r, 1312, Národní knihovna České republiky, Praha. 


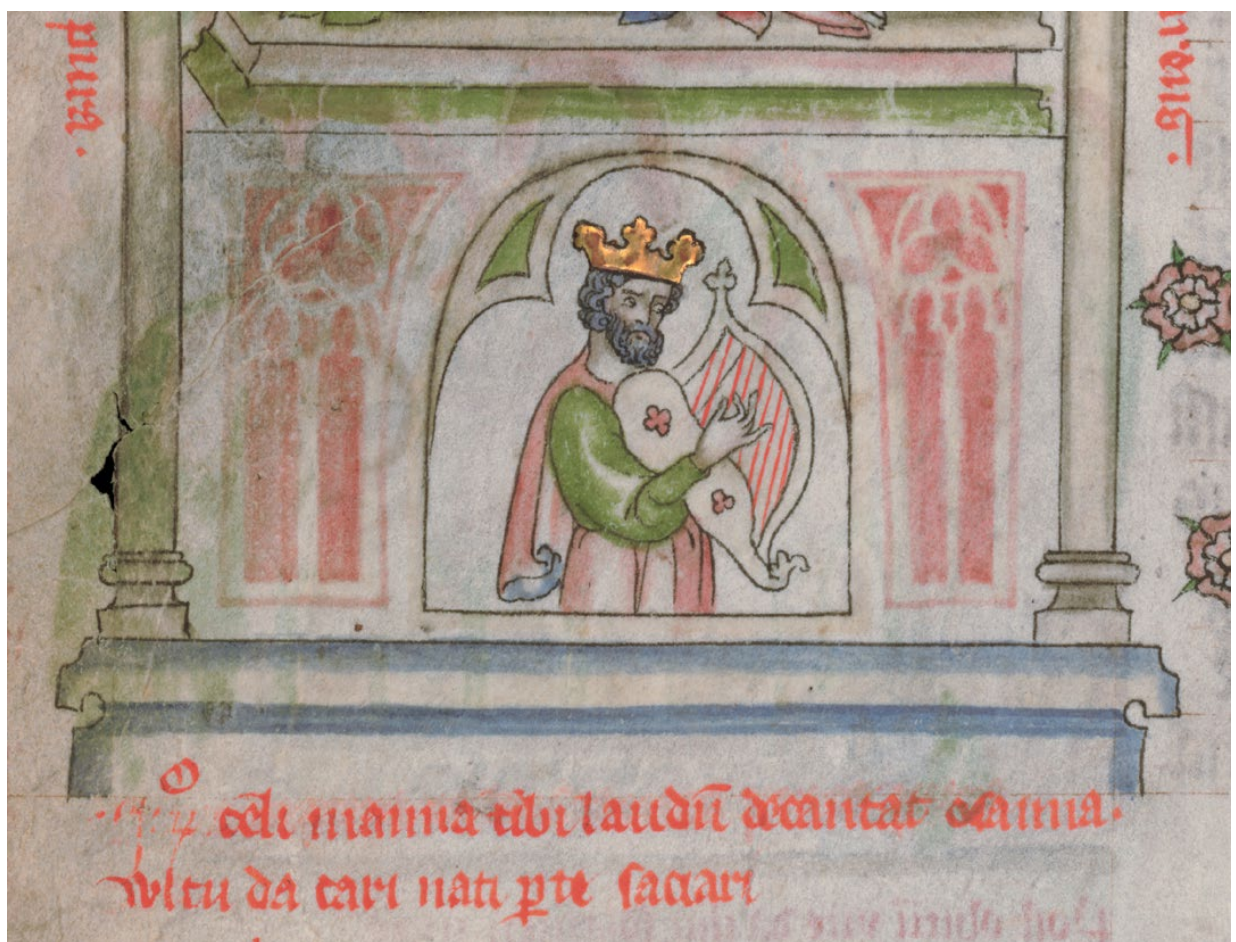

Figure 16. Detail. St. David, Coronation of the Virgin, Passional of Abbess Cunegund, MS XIV A 17, fol. 8r, 1312, Národní knihovna České republiky, Praha.

surrounding the fol. 9r image of King David leads me to argue that the Passional also played a vital role in the fulfilment of this dynastic duty. When the 1312 section of the Passional was created, the dynastic future of the Premyslids lay in the hands of Cunegund's niece, Queen Eliška, who had married John of Luxembourg. The rubric title above the fol. 9r Resurrection reads, Vim superatis mortis surgit Christe leo fortis. This may be translated as, 'Christ, you conquer the power of death; the brave lion arises'. I therefore suggest that surgit [...] leo fortis (the brave lion arises) also references the rampant lion of the Premyslid coat of arms, pictured on fol. 1v (Figure 6). This particular 'positive other', King David, therefore takes on a specific and crucial role by performatively prophesying and thus invoking a resurgence of Premyslid power.

\section{Conclusion}

Colda's introductory speech, which opens the first treatise, includes the following advice to Cunegund and her fellow sisters, [...] ad arma passionis dominice prudenti use consilio convola/tis ut tanto adversarium vinca/tis securius quanto forciorum / armaturarum asseruit vobis usus. ${ }^{101}$ Severe insults were inflicted upon Christ by the Instruments of the

\footnotetext{
$101[. .$.$] fly to the weapons of the Passion of Our Lord, as surely as you will have need of strong weapons so that you$ may more safely win against the enemy. NKČR, MS XIV A 17, fols. 2rb5-2rb8.
} 
Passion, causing him great suffering and it is this suffering that is redemptive. The artist, by vividly illustrating the violent behaviour of the 'others', was, I believe, also illustrating the cause of Man's future Salvation. The nuns were to meditate upon the weapons that injured Christ, and to empathise with his suffering, ut possitis stare adversus in/fidias dyaboli... adversus sathanam /victoriose confligere [....${ }^{102}$ Through the Passional images, the figures of medieval society's ostracized 'others '- the villain, the violent soldier and the Jew - become the embodiment of sinful wickedness, as they are shown exercising their brutality on the meek figures of the sponsa and Christ. In this manner, through prayer and deep spiritual contemplation of the Passional illustrations, the nuns might, metaphorically, turn the weapons back upon the personification of evil, described severally as the enemy, the Devil and Satan.

It has been demonstrated that the artist employed stereotypical details to represent the 'others' in the narrative, directly linking them to their medieval counterparts. He illustrates them in contemporary dress with important visual indicators: the treacherous villain's plain tunic and tousled hair; the vicious soldiers' heraldic arms; the Jews' exaggerated facial features, ringleted hair and flowing beards; the Phrygian and conical Jewish hats. Some small reprieve is to be found in the images of benign Jews but overwhelmingly the 'others' in the Passional illustrations are unsympathetically depicted. Readers of the Passional would have identified these familiar cues in dress and appearance as signalling specific social pariahs. The viewer is intended to be repulsed by them and their behaviour, and is encouraged to mock, blame, criticise, despise and totally reject these negatively illustrated outsiders, but also to appreciate their important role in bringing about Mankind's ultimate salvation, and the salvation of each individual nun who might pray and meditate upon these images.

\section{Bibliography}

\section{Archival Sources}

Bodleian Library, Oxford, Douce, MS 180.

British Library, London, Psalter of Robert De Lisle, Arundel, MS 83 II.

Fitzwilliam Museum, Cambridge, MS 298.

J. Paul Getty Museum, Los Angeles, California, MS Ludwig X17 (83 MN 126).

Národní knihovna České republiky, Praha, Passional of Abbess Cunegund, MS XIV A 17; MS XVI E 12; MS XXIII C 120; MS XIII C 124; MS XIII E 14c.

Österreichische Nationalbibliothek, Wien, MS 370.

Victoria and Albert Museum, London, Marnhull Orphrey, inv. No. T31-19 36.

\section{Internet sources}

Jewish Virtual Library. https://www.jewishvirtuallibrary.org/bohemia.

\section{Literature}

BALE, Anthony: The Jew in the Medieval Book. Cambridge 2006.

BARTLETT, Robert: The Ostsiedlung. In: DITCHBURN, David - MACLEAN, Simon - MACKAY, Angus (eds.): Atlas of Medieval Europe. Oxford 2007, pp. 123-125.

BAUMGARTEN, Elisheva: Practicing Piety in Medieval Ashkenaz : Men, Women, and Everyday Religious Observance. Philadelphia 2014, pp. 149-178.

BENEŠOVSKÁ, Klára (ed.): A Royal Marriage : Elisabeth Premyslid and John of Luxembourg 1310. Exhibition catalogue, English edition. Prague 2011.

$\overline{102}[\ldots]$ that you may be able to withstand the snares of the Devil $[\ldots]$ to fight against Satan with victory [...]. NKČR, MS XIV A 17, fols. 2ra24-27. 
BINSKI, Paul: Westminster Abbey and the Plantagenets : Kingship and the Representation of Power 1200-1400. New Haven - London 1995.

BLAHA, Ondřej - DITTMANN, Robert - ULIČNÁ, Lenka (eds.): Knaanic Language : Structure and Historical Background. Praha 2013.

BLAHA, Ondřej - DITTMANN, Robert - KOMÁREK, Karel (eds.): Knaanské glosy ve středověkých hebrejských rukopisech s vazbou na české země / Knaanic Glosses in Medieval Hebrew Manuscripts associated with the Czech Lands. Praha 2015.

BLECHOVÁ, Lenka et al. (eds.): Prameny k dějinám Židův Čechách a na Moravě / Sources for the History of Jews in Bohemia and Moravia. Praha 2015 (no. 47, 51, 54).

BRAUER, Barbara: The Třeboň Resurrection : Retrospection and Innovation. Umění 31, 1983, no. 2, pp. $150-158$.

BURTON, Richard: Prague : A Cultural and Literary History. Oxford 2003.

CAMILLE, Michael: Image on the Edge: The Margins of Medieval Art. London 1992.

DE VORAGINE, Jacobus - STACE, Christopher (transl.): The Golden Legend. New York 1998.

DURAND OF MENDE, William: Rationale divinorum officiorum, Books 2-3. In: THIBODEAU, Timothy M. (transl.): William Durand: On the Clergy and Their Vestments. Chicago 2010.

FIALA, Zdeněk (ed.) - HEŘMANSKÝ, František (transl.): Kronika Zbraslavská : Chronicon Aulae Regiae. Prague 1952.

HAMBURGER, Jeffrey: The Rothschild Canticles : Art and Mysticism in Flanders and the Rhineland c. 1300. New Haven 1990.

HAMBURGER, Jeffrey - MARX, Petra - MARTI, Susan: The Time of the Orders 1200-1500 : An Introduction. In: HAMBURGER, Jeffrey - MARTI, Susan (eds.): Crown and Veil : Female Monasticism from the Fifth Century to the Fifteenth Centuries. New York 2008, pp. 41-75.

HEER, Friedrich: The Medieval World 1100-1300. London 1962.

HERSCH, Philip: Anti-semitism 1096-1306. In: DITCHBURN, David - MACLEAN, Simon - MACKAY, Angus (eds.): Atlas of Medieval Europe. Oxford 2007, pp. 180-182.

HOOD, John Y. B.: Aquinas and the Jews. Philadelphia 1995.

JORDAN, William Chester: The Last Torment of Christ : An Image of the Jews in Ancient and Medieval Exegesis, Art and Drama. The Jewish Quarterly Review 1/2, July-October 1987, New Series 78, pp. 21-47.

LIPTON, Sara: Dark Mirror: The Medieval Origins of Anti-Jewish Iconography. New York 2014.

METZGER, Thérèse - METZGER, Mendel: Jewish Life in the Middle Ages : Illuminated Hebrew Manuscripts of the Thirteenth to the Sixteenth Centuries. New York 1982.

MUSCHIOL, Gisela: Time and Space : Liturgy and Rite in Female Monasteries of the Middle Ages. In: HAMBURGER, Jeffrey F. - MARTI, Susan (eds.): Crown and Veil : Female Monasticism from the Fifth Century to the Fifteenth Centuries. New York 2008, pp. 191-206.

PSEUDO-BONAVENTURA: Meditationes vitae Christi. In: RAGUSA, Isa - GREEN, Rosalie B. (eds.): Meditations on the Life of Christ : An Illustrated Manuscript of the Fourteenth Century. Princeton 1977.

REITINGER, Lukáš - SOUKUP, Daniel: The Krumlov Liber Depictus : On its Creation and Depiction of Jews. Judaica Bohemiae 50, 2015, no. 2, pp. 5-44.

ROSEWELL, Roger: Medieval Wall Paintings in English and Welsh Churches. Woodbridge 2008.

SCHILLER, Gertrude: Iconography of Christian Art, I/2. London 1971-1972.

SCOTT, Margaret: Medieval Dress and Fashion. London 2009.

SCOTT, Margaret: Fashion in the Middle Ages. Los Angeles 2011.

SOUKUP, Daniel: Mor, masakr, Maria : Protižidovské aspekty pozdně středověké zbožnosti / Plague, massacre, Mary : Anti-Jewish Aspects of Late Medieval Piety. In: KUBINOVÁ, Kateřina et al. (eds.): Karel IV. a Emauzy: Liturgie - text - obraz / Charles IV and the Emmaus Monastery: Liturgy - text - picture. Praha 2017, pp. 266-281.

STEJSKAL, Karel: Pasionál Přemyslovny Kunhuty / The Passional of Abbess Cunegund. In: URBÁNKOVÁ, Emma - STEJSKAL, Karel: Pasionál Přemyslovny Kunhuty : Passionale Abbatissae Cunegundis / The Passional of Abbess Cunegund. Praha 1975, pp. 21-146.

STRICKLAND, Debra Higgs: Saracens, Demons and Jews : Making Monsters in Medieval Art. Princeton Oxford 2003.

The Holy Bible, King James' version. London 1957.

The New English Bible, New Testament. Oxford 1970.

TOUSSAINT, Gia: Das Passional der Kunigunde von Böhmen : Bildrhetorik und Spiritualität / The Passional of Abbess Cunegund: The Artistic Eloquence and Spirituality. Paderborn 2003. 
URBÁNKOVÁ, Emma: Historický úvod / Historical introduction. In: URBÁNKOVÁ, Emma - STEJSKAL, Karel: Pasionál Přemyslovny Kunhuty: Passionale Abbatissae Cunegundis / The Passional of Abbess Cunegund. Praha 1975, pp. 11-20.

VALLEY, Eli: The Great Jewish Cities of Central and Eastern Europe : A Travel Guide and Resource Book to Prague, Warsaw, Cracow and Budapest. Oxford 2005.

VAN BUREN, Anne - WIECK, Roger S.: Illuminating Fashion : Dress in the Art of Medieval France and the Netherlands, 1325-1515. New York 2011.

VAN STRATEN, Jits: The Origin of Ashkenazi Jewry: The Controversy Unravelled. Berlin - New York 2011.

VILIKOVSKÝ, Jan: Písemnictví českého středověku / Medieval Czech Literature. Praha 1948.

VLČEK SCHURR, Jennifer: The Master of Abbess Cunegund's Passional : An Exploration of Style, Iconography and Nationality. University of Glasgow 2019.

VLČEK SCHURR, Jennifer: Kunigunde: 'Bartered Bride’ and Bride of Christ. In: ANTONÍN MALANÍKOVÁ, Michaela - RYWIKOVÁ, Daniela (eds.): Premodern History and Art through the Prism of Gender. Washington D.C. (forthcoming publication).

\section{Summary \\ Illustrating the Ostracized : the Depiction of Villain, Soldier and Jew in the Passional of Abbess Cunegund}

In the illustrations of the opening treatise of the so-called Passional of Abbess Cunegund, a strikingly prominent place is given to malevolent 'others': to those on the margins of society, and particularly to Jews. The manuscript was written in turbulent times at the beginning of the fourteenth century: a time of unrest when Prague streets had recently been the arena of fierce and bloody military skirmishes as power shifted from Henry of Carinthia to John of Luxembourg, and when the Jews were frequently the object of distrust and superstition, and associated with alleged blood libel. It was written and illustrated a mere fourteen years after the Jews of Europe had suffered the horrifying repercussions of the Rintfleisch accusations. The specific characters of villain, soldier and Jew, illustrated on nine of the eighteen sides of manuscript, not only act out their parts in the metaphorical tale or parable around which the treatise is composed, and in the recounting of Christ's Passion, but also provide today's observers with a glimpse of certain aspects of contemporary, medieval Czech society. The barbaric villain finds his counterparts in wider medieval art, as do the soldiers appearing in the guise of medieval men-at-arms, however they are afforded specific, iconographic details that not only speak of local attitudes, but contribute to the images' role as meditative aids. It is the Jews, however, who are the most prominent "others" in this work. The main narrative theme of the treatise is an analysis of the instruments of Christ's Passion, developed into an instructional sermon. The Jews, together with the occasional Roman, are therefore essentially depicted as the antagonists in the action. The context for the reception of these images, however, was a strong Jewish presence in Prague that had developed over several centuries but that was still subject to the considerable tensions of the period. The villain, soldier and Jew, all wearing contemporary dress, characterized evil, violence, threat and ill-doing. Their artistic portrayal conforms, to a large extent, to norms of medieval iconographic convention. Caricatured facial features, the depiction of hair, distorted posture and an emphasis on dress, all contribute to presenting an instantly recognisable 'other'. Despite being distasteful to a modern viewer, these details are of considerable interest and importance. As a reflection of observations made through the eyes of a contemporary observer, they offer insight into the fears, superstitions and the mind-sets and attitudes of the age. Some details of iconography are particularly remarkable for their individuality, appearing to be based on observations taken from contemporary Czech society, others in offering a particular political message, such as the apparent use of the image of King David as a surrogate for the Premyslid dynastic kings of Bohemia. The artist also appears to use a vocabulary of different head wear to differentiate between sympathetic and unsympathetic 'others' within the narrative. The majority, however, fall into the latter category and, in exercising their brutality, become 
objects of loathing and the personification of the Devil. The nuns, for whom this treatise was prepared, are therefore entreated to guard themselves rigorously against them. There is, however an ultimate dichotomy, for the objects used by these wicked 'others' to inflict their suffering on Christ, become his weapons as his suffering is transformed into his strength. Christ's suffering is Mankind's salvation. On the pages of the manuscript, the illustrations of the perpetrators who wielded these implements and the implements themselves as the Arma Christi-become objects upon which to be meditated, and therefore a route towards the soul's salvation. 